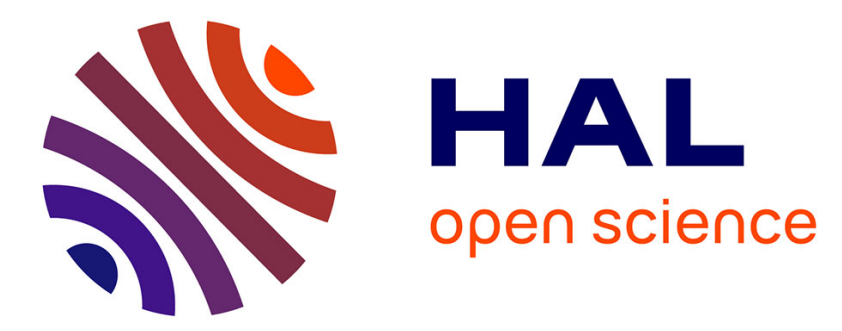

\title{
Soil organic matter quality and microbial catabolic functions along a gradient of wildfire history in a Mediterranean ecosystem
}

\author{
R. Guénon, M. Vennetier, N. Dupuy, F. Ziarellid, R Gros
}

\section{- To cite this version:}

R. Guénon, M. Vennetier, N. Dupuy, F. Ziarellid, R Gros. Soil organic matter quality and microbial catabolic functions along a gradient of wildfire history in a Mediterranean ecosystem. Applied Soil Ecology, 2011, 48 (1), p. 81 - p. 93. hal-00637647

\section{HAL Id: hal-00637647 https://hal.science/hal-00637647}

Submitted on 2 Nov 2011

HAL is a multi-disciplinary open access archive for the deposit and dissemination of scientific research documents, whether they are published or not. The documents may come from teaching and research institutions in France or abroad, or from public or private research centers.
L'archive ouverte pluridisciplinaire HAL, est destinée au dépôt et à la diffusion de documents scientifiques de niveau recherche, publiés ou non, émanant des établissements d'enseignement et de recherche français ou étrangers, des laboratoires publics ou privés. 
Guénon R., Vennetier M., Dupuy N., Ziarelli F. and Gros R. (2011) Soil organic matter quality and microbial catabolic functions along a gradient of wildfire history in a Mediterranean ecosystem, Applied Soil Ecology 48 (1) 81-93

Author-produced version of the final draft post-refeering

the original publication is available at www.elsevier.com/locate/issn/09291393 - doi:10.1016/j.apsoil.2011.01.004

Soil organic matter quality and microbial catabolic functions along a gradient of wildfire history in a Mediterranean ecosystem

\author{
René Guénon ${ }^{\mathrm{a}}$, Michel Vennetier ${ }^{\mathrm{b}, \mathrm{e}}$, Nathalie Dupuy ${ }^{\mathrm{c}}$, Fabio Ziarelli ${ }^{\mathrm{d}}$, Raphaël Gros ${ }^{\mathrm{a}, \mathrm{e}}$ \\ a - Institut méditerranéen d'Ecologie et de Paléoécologie (IMEP), UMR CNRS 6116, Equipe Ecologie Microbienne et \\ Biotechnologies, Service 452, Université Paul Cézanne, Faculté des Sciences et Techniques, 13397 Marseille cedex 20, \\ France \\ b - Cemagref, 3275 Route de Cézanne, CS 40061, 13182 Aix en Provence Cedex 5, France \\ c - Institut des Sciences Moléculaires de Marseille, UMR CNRS 6263, Équipe AD2EM, Groupe Systèmes Chimiques \\ Complexes, Service 451, Université Paul Cézanne Aix-Marseille, Faculté des Sciences et Techniques de Saint-Jérôme, \\ 13397 Marseille cedex 20, France \\ d - Spectropole, Fédération des Sciences Chimiques de Marseille, Faculté des Sciences et Techniques de Saint-Jérôme, \\ 13397 Marseille cedex 20, France \\ e - Fédération de Recherche ECCOREV (FR3098), Europôle Méditerranéen de l'Arbois, Bâtiment du CEREGE BP \\ 80,13545 Aix en Provence cedex 4, France \\ * corresponding author
}

Abstract

The principal aim of this research was to determine the influence of an increasing wildfire history on the recovery at short and long term of soil organic matter (SOM) composition and microbial properties. The contemporary wildfire events (since 1950) were recorded for 27 plots located on the siliceous part of the French Mediterranean region (Maures mountain ranges). A wildfire history index was built, tested and calculated in order to display numerical values representative of the different wildfire history parameters (i.e. number of fires, time since fire and mean fire interval). Microbial basal respiration and biomass were analysed as well as intensity of the use of $31 \mathrm{C}$-substrates, catabolic diversity and C-substrates utilisation profiles. Furthermore, a qualitative characterisation of the SOM was carried out by solid state ${ }^{13} \mathrm{C}$ NMR. Potential drivers of the microbial recovery were identified by studying the relationships between microbial activities and chemical functions of SOM. Our results showed that fire histories resulting in considerable losses or alterations of SOM, such as recent or close fires, decreased the microbial catabolic evenness. This could be attributed to a preferential utilisation of $\mathrm{N}$-containing compounds and complex substrates such as aromatic and polymers reflecting a greater $\mathrm{N}$ microbial demand and a selection of specific catabolic functions. Moreover, a large number of fires (4 fires in 57 years compared to 1-2) resulted in lasting degradation of the relative intensity of methyl $\mathrm{C}$ function in polymethylene, $O$-Alkyl $\mathrm{C}$, aromatic $\mathrm{C}$ and phenolic $\mathrm{C}$ functions inducing a slow-down in recovery of microbial properties. These results also confirm our hypothesis that some chemical functions of SOM can be in equilibrium with wildfire history. Finally, this research demonstrates that FT-NIR analysis can be used as a valuable tool to assess both the wildfire history and the vulnerability of soil quality to shifts in historical fire regimes.

Keywords: Fire recurrence, recovery, Biolog, catabolic evenness, ${ }^{13} \mathrm{C}$ NMR, FT-NIR spectroscopy.

\title{
1. Introduction
}

Shifts in historical fire regimes have been observed both in eastern coast of the Iberian Peninsula and the southern French Mediterranean area (Pausas et al., 2004; Curt et al., 2009). The abandonment of agricultural lands from the late '60s, resulting in the closure of open areas, accentuated by a climate of drought, increased the size of fires, and thus locally the fire frequency. Repeated burnings progressively impoverish soils in organic matter and nutrients (Reich et al., 2001; Boerner and Brinkman, 2003) to such a point that soil microbial communities and their mineralising activities may be altered on a long-term. In spite of the fact that fires reduce competition in communities in the first regenerative phases (Vilà and Sardans, 1999), shorter periods to recover nutrients through microbial mineralisation, may lead in the long term to a reduction in site productivity and to a loss of ecosystem resilience.

Cumulative effects of fires are evidenced at plant community level (Curt et al., 2009). Soils studies have focused on the effects of a single wildfire on short-term nutrient and SOM dynamics (Carreira and Niells, 1992; Knicker et al., 2005; Knicker, 2007) and depletion of soil microbial biomass or changes in 
microbial catabolic diversity (Hernández et al., 1997; D’Ascoli et al., 2005; Zhou et al., 2009). The stability of soil microbial communities and the ability of their activities to recover may depend on nutrient availability (Moore et al., 1993) which is directly linked to both SOM content and quality remaining after disturbance or brought by the vegetation (De Angelis et al., 1989; Hart et al., 2005). The degree of change in SOM depends on (i) fire regime factors such as intensity, duration and recurrence (Flannigan et al., 2000 ; Cécillon et al., 2009), (ii) initial soil chemical and physical properties (Knicker, 2007), and (iii) local conditions such as vegetation composition and topography (Certini et al., 2005). If cumulative effects of repeated prescribed fires on microbial activities were evidenced (Reich et al., 2001; Boerner and Brinkman, 2003), to date little emphasis has been placed on quantifying the trends in long-term recovery of soil organic matter (SOM) quality and microbial properties with an increase in wildfire frequency. Moreover, a better understanding of relationships at the long term between wildfire history and soil quality can have direct implications in choice of land management options (Scheffer and Carpenter, 2003).

In this study, soil microbial properties were hypothesised to be in equilibrium with wildfire history, up to a limit which depends on number of fires, time since fire and also fire interval. A high fire frequency (4 fires in 57 years compared to 1-2), a short time since fire (4 years compared to 17 or 57 years) and/or a short mean fire interval $(<12$ years compared to $>20$ years) would cause lasting degradation of the soil organic matter resulting in a breakdown of microbial relationship to wildfire and a change in trends of recovery. Moreover, the quality of SOM is expected to be primary driving factors by which the vegetation influences soil microbial properties (Hart et al., 2005). Our objectives were (i) to assess the effect of various wildfire histories on the soil organic matter quality (i.e. chemical functions assessed by solid state ${ }^{13} \mathrm{C}-\mathrm{NMR}$ spectroscopy) and microbial properties (i.e. catabolic level physiological profiles, biomass and basal respiration), (ii) to identify the wildfire history threshold resulting in an abrupt change of soil properties and (iii) to identify the chemical functions of SOM better related to the microbial properties. Finally, we aimed to assess the potential of Fourier Transform Near Infra-Red (FT-NIR) spectroscopy for predicting soil microbial properties and wildfire history parameters. FT-NIR spectroscopy is a rapid and simple analytical technique involving diffuse reflectance measurement in the NIR region $\left(4500-10000 \mathrm{~cm}^{-1}\right)$. NIR analysis is now widely used to predict soil chemical and biological properties (e.g. Brunet et al., 2007; Cécillon et al., 2008) and specific soil quality indices (Cécillon et al., 2009). So, FT-NIR spectroscopy could be a valuable tool for wildfire history and soil characterisation and management. A wildfire history index was built, tested and calculated in order to display numerical values representative of the different wildfire history parameters (i.e. number of fires, time since fire and mean fire interval) that affects the soils properties and their recovery.

\section{Materials and methods}

\subsection{Study area}

The study was conducted in part of the Maures mountain range (Var, southern France, $43^{\circ} 20^{\prime} \mathrm{N}$ and $\left.6^{\circ} 37^{\prime} \mathrm{E}\right)$. The region is characterised by a Mediterranean climate with dry, hot summers and wet, temperate winters. The mean annual precipitation is $920 \mathrm{~mm}(1962-2003)$. The average monthly temperature varies from $7^{\circ} \mathrm{C}$ in January to $22^{\circ} \mathrm{C}$ in July, with mean annual temperatures close to $14^{\circ} \mathrm{C}$. The study area $\left(90 \mathrm{~km}^{2}\right)$ presents a range of altitude from 100 to $400 \mathrm{~m}$ above sea level. The mother rock is a gneiss migmatitic (crystalline siliceous rock) composed of ferro-magnesian minerals (micas, amphibols). The loamy sand soils are classified as Dystric Leptosol and Dystric Cambisol (IUSS Working Group WRB, 2006). The study area is characterised by a heterogeneous mosaic of Mediterranean forest ecosystems generated by various wildfire frequencies. At the early stage of succession (i.e. following forest fires), plant communities are dominated by herbaceous and fast growing species such as Cistus monspeliensis L., Calycotome spinosa L., Erica arborea L. and Quercus suber L. At the later successional stage (i.e. with no fire for at least 57 years), closed forests are dominated by a tree stratum of Quercus suber L., Quercus ilex and Pinus pinaster Aiton subsp. pinaster. 
Guénon R., Vennetier M., Dupuy N., Ziarelli F. and Gros R. (2011) Soil organic matter quality and microbial catabolic functions along a gradient of

version of the final draft post-refeering

the original publication is available at www.elsevier.com/locate/issn/09291393 - doi:10.1016/j.apsoil.2011.01.004

Table 1: Plots sampled in this study, together with their geographic location and some soil and vegetation characteristics

\begin{tabular}{|c|c|c|c|c|c|c|c|}
\hline $\begin{array}{l}\text { Sample } \\
\text { code }\end{array}$ & Latitude/longitude & $\begin{array}{l}\text { Altitude/ } \\
\text { m.a.s.l }\end{array}$ & $\begin{array}{l}\text { Slope/ } \\
\%\end{array}$ & $\begin{array}{l}\text { Textural } \\
\text { classification }\end{array}$ & $\begin{array}{l}\text { Soil type } \\
\text { (WRB) }\end{array}$ & $\begin{array}{l}\text { Vegetation } \\
\text { structure }\end{array}$ & Dominant species \\
\hline 1 & $43^{\circ} 19^{\prime} 46^{\prime \prime} \mathrm{N} / 6^{\circ} 34^{\prime} 03^{\prime \prime} \mathrm{E}$ & 80 & 15.9 & \multirow{5}{*}{ Sandy Loam } & \multirow{5}{*}{$\begin{array}{l}\text { Dystric } \\
\text { Cambisol }\end{array}$} & \multirow{5}{*}{$\begin{array}{l}\text { Closed oak } \\
\text { forest }\end{array}$} & \multirow{5}{*}{$\begin{array}{l}\text { Quercus suber, Quercus } \\
\text { ilex, Quercus pubescens }\end{array}$} \\
\hline 2 & $43^{\circ} 20^{\prime} 12^{\prime \prime} \mathrm{N} / 6^{\circ} 34^{\prime} 19^{\prime \prime} \mathrm{E}$ & 100 & 26.8 & & & & \\
\hline 3 & $43^{\circ} 20^{\prime} 09^{\prime \prime} \mathrm{N} / 6^{\circ} 34^{\prime} 15^{\prime \prime} \mathrm{E}$ & 90 & 26.7 & & & & \\
\hline 4 & $43^{\circ} 20^{\prime} 07^{\prime \prime N} / 6^{\circ} 34^{\prime} 07^{\prime \prime E}$ & 60 & 7.8 & & & & \\
\hline 5 & $43^{\circ} 26^{\prime} 26^{\prime \prime N} / 6^{\prime} 35^{\prime} 49^{\prime \prime} \mathrm{E}$ & 120 & 11.3 & & & & \\
\hline 6 & $43^{\circ} 22^{\prime} 06^{\prime \prime} \mathrm{N} / 6^{\circ} 36^{\prime} 06^{\prime \prime} \mathrm{E}$ & 260 & 26.2 & \multirow{5}{*}{ Sandy Loam } & \multirow{5}{*}{$\begin{array}{l}\text { Dystric } \\
\text { Leptosol }\end{array}$} & \multirow{5}{*}{$\begin{array}{l}\text { Cork oak with } \\
\text { high maquis }\end{array}$} & \multirow{5}{*}{$\begin{array}{l}\text { Quercus suber, Erica } \\
\text { arborea, Arbustus } \\
\text { unedo, Cistus } \\
\text { monspeliensis, } \\
\text { Calycotome spinosa }\end{array}$} \\
\hline 7 & $43^{\circ} 25^{\prime} 46^{\prime \prime N} / 6^{\circ} 39^{\prime} 07^{\prime \prime E}$ & 100 & 19.0 & & & & \\
\hline 8 & $43^{\circ} 25^{\prime} 31^{\prime \prime N} / 6^{\circ} 39^{\prime} 03^{\prime \prime E}$ & 100 & 27.0 & & & & \\
\hline 9 & $43^{\circ} 22^{\prime} 15^{\prime \prime} \mathrm{N} / 6^{\circ} 35^{\prime} 37^{\prime \prime E}$ & 300 & 28.1 & & & & \\
\hline 10 & $43^{\circ} 19^{\prime} 23^{\prime \prime N} / 6^{\circ} 35^{\prime} 47^{\prime \prime E}$ & 60 & 11.0 & & & & \\
\hline 11 & $43^{\circ} 18^{\prime} 53^{\prime \prime N} / 6^{\circ} 36^{\prime} 21^{\prime \prime E}$ & 170 & 44.5 & \multirow{4}{*}{ Sandy Loam } & \multirow{4}{*}{$\begin{array}{l}\text { Dystric } \\
\text { Leptosol }\end{array}$} & \multirow{4}{*}{$\begin{array}{l}\text { Cork oak with } \\
\text { high maquis }\end{array}$} & \multirow{4}{*}{$\begin{array}{l}\text { Quercus suber, Arbustus } \\
\text { unedo, Erica arborea, } \\
\text { Calycotome spinosa, } \\
\text { Laburnum vulgare }\end{array}$} \\
\hline 12 & $43^{\circ} 18^{\prime} 45^{\prime \prime N} / 6^{\circ} 36^{\prime} 08^{\prime \prime} \mathrm{E}$ & 200 & 22.8 & & & & \\
\hline 13 & $43^{\circ} 22^{\prime} 27^{\prime \prime N} / 6^{\circ} 36^{\prime} 29^{\prime \prime E}$ & 320 & 38.2 & & & & \\
\hline 14 & $43^{\circ} 22^{\prime} 32^{\prime \prime N} / 6^{\circ} 36^{\prime} 27^{\prime \prime E}$ & 360 & 21.2 & & & & \\
\hline 15 & $43^{\circ} 19^{\prime} 23^{\prime \prime N} / 6^{\circ} 40^{\prime} 15^{\prime \prime} \mathrm{E}$ & 100 & 20.7 & & & \multirow{5}{*}{$\begin{array}{l}\text { Low maquis } \\
\text { under Cork } \\
\text { oak }\end{array}$} & \multirow{5}{*}{$\begin{array}{l}\text { Cistus monspeliensis, } \\
\text { Calycotome spinosa, } \\
\text { Cistus salviifolius, Erica } \\
\text { arborea, Quercus suber }\end{array}$} \\
\hline 16 & $43^{\circ} 20^{\prime} 51^{\prime \prime} \mathrm{N} / 6^{\circ} 37^{\prime} 26^{\prime \prime} \mathrm{E}$ & 280 & 41.7 & \multirow{4}{*}{ Sandy Loam } & \multirow{4}{*}{$\begin{array}{l}\text { Dystric } \\
\text { Leptosol }\end{array}$} & & \\
\hline 17 & $43^{\circ} 20^{\prime} 51^{\prime \prime N} / 6^{\circ} 37^{\prime} 26^{\prime \prime} \mathrm{E}$ & 280 & 30.9 & & & & \\
\hline 18 & $43^{\circ} 21^{\prime} 06^{\prime \prime N} / 6^{\circ} 36^{\prime} 57^{\prime \prime E}$ & 270 & 25.9 & & & & \\
\hline 19 & $43^{\circ} 22^{\prime} 04^{\prime \prime N} / 6^{\circ} 40^{\prime} 39^{\prime \prime} \mathrm{E}$ & 160 & 27.0 & & & & \\
\hline 20 & $43^{\circ} 22^{\prime} 01^{\prime \prime N} / 6^{\circ} 35^{\prime} 12^{\prime \prime E}$ & 120 & 33.7 & \multirow{3}{*}{ Sandy Loam } & \multirow{5}{*}{$\begin{array}{l}\text { Dystric } \\
\text { Leptosol }\end{array}$} & \multirow{5}{*}{$\begin{array}{l}\text { Low maquis } \\
\text { under sparse } \\
\text { Cork oak }\end{array}$} & \multirow{5}{*}{$\begin{array}{l}\text { Cistus salviifolius, } \\
\text { Cistus monspeliensis, } \\
\text { Calycotome spinosa, } \\
\text { Quercus Suber }\end{array}$} \\
\hline 21 & $43^{\circ} 22^{\prime} 06^{\prime \prime} \mathrm{N} / 6^{\circ} 35^{\prime} 02^{\prime \prime} \mathrm{E}$ & 130 & 17.2 & & & & \\
\hline 22 & $43^{\circ} 21^{\prime} 57^{\prime \prime N} / 6^{\circ} 35^{\prime} 03^{\prime \prime E}$ & 100 & 22.3 & & & & \\
\hline 23 & $43^{\circ} 21^{\prime} 05^{\prime \prime N} / 6^{\circ} 32^{\prime} 39^{\prime \prime E}$ & 180 & 28.6 & \multirow[t]{2}{*}{ Loamy Sand } & & & \\
\hline 24 & $43^{\circ} 21^{\prime} 06^{\prime \prime N} / 6^{\circ} 32^{\prime} 39^{\prime \prime} \mathrm{E}$ & 180 & 30 & & & & \\
\hline 25 & $43^{\circ} 18^{\prime} 27^{\prime \prime} \mathrm{N} / 6^{\circ} 36^{\prime} 02^{\prime \prime} \mathrm{E}$ & 220 & 12.0 & \multirow{3}{*}{ Loamy Sand } & \multirow{3}{*}{$\begin{array}{l}\text { Dystric } \\
\text { Leptosol }\end{array}$} & \multirow{3}{*}{$\begin{array}{l}\text { Charred cork } \\
\text { oak, sparse } \\
\text { herbaceous } \\
\text { and resprouts }\end{array}$} & \multirow{3}{*}{$\begin{array}{l}\text { Quercus suber, Cistus } \\
\text { monspeliensis, } \\
\text { Bituminnella } \\
\text { bituminosa, Lotus sp. }\end{array}$} \\
\hline 26 & $43^{\circ} 18^{\prime} 32^{\prime \prime} \mathrm{N} / 6^{\circ} 35^{\prime} 57^{\prime \prime} \mathrm{E}$ & 280 & 30.0 & & & & \\
\hline 27 & $43^{\circ} 18^{\prime} 34^{\prime \prime} \mathrm{N} / 6^{\circ} 35^{\prime} 24^{\prime \prime} \mathrm{E}$ & 220 & 18.0 & & & & \\
\hline
\end{tabular}


Guénon R., Vennetier M., Dupuy N., Ziarelli F. and Gros R. (2011) Soil organic matter
wildfire history in a Mediterranean ecosystem, Applied Soil Ecology 48 (1) 81-93

Author-produced version of the final draft post-refeering

the original publication is available at www.elsevier.com/locate/issn/09291393 - doi:10.1016/j.apsoil.2011.01.004

Table 2: Wildfire history parameters of the plots sampled in 2007, 2008 and 2009

\begin{tabular}{|c|c|c|c|c|c|c|c|c|c|c|c|}
\hline \multirow[b]{2}{*}{$\begin{array}{l}\text { Sample } \\
\text { code }\end{array}$} & \multicolumn{2}{|l|}{ Sampling year } & \multicolumn{3}{|l|}{2007} & \multicolumn{3}{|l|}{2008} & \multicolumn{3}{|l|}{2009} \\
\hline & Wildfire history parameters & $\mathrm{NF}$ & TSF & MFI & WHI & TSF & MFI & WHI & TSF & MFI & WHI \\
\hline & Date of fire events & & & & & & & & & & \\
\hline 1 & Not burned since 1950 & 1 & 57 & 57 & 0.132 & 58 & 58 & 0.131 & 59 & 59 & 0.130 \\
\hline 2 & Not burned since 1950 & 1 & 57 & 57 & 0.132 & 58 & 58 & 0.131 & 59 & 59 & 0.130 \\
\hline 3 & Not burned since 1950 & 1 & 57 & 57 & 0.132 & 58 & 58 & 0.131 & 59 & 59 & 0.130 \\
\hline 4 & Not burned since 1950 & 1 & 57 & 57 & 0.132 & 58 & 58 & 0.131 & & & \\
\hline 5 & Not burned since 1950 & 1 & 57 & 57 & 0.132 & 58 & 58 & 0.131 & & & \\
\hline 6 & 1982 & 1 & 25 & 28.5 & 0.200 & 26 & 29 & 0.196 & & & \\
\hline 7 & 1990 & 1 & 17 & 28.5 & 0.244 & 18 & 29 & 0.236 & & & \\
\hline 8 & $1982 / 1959$ & 2 & & & & 18 & 24.5 & 0.243 & & & \\
\hline 9 & $1990 / 1962$ & 2 & & & & 18 & 23 & 0.278 & & & \\
\hline 10 & $1990 / 1964$ & 2 & 17 & 21.5 & 0.286 & 18 & 22 & 0.280 & & & \\
\hline 11 & $1990 / 1982 / 1978 / 1962$ & 4 & 17 & 11.25 & 0.394 & 18 & 11.5 & 0.386 & 19 & 11.75 & 0.378 \\
\hline 12 & $1990 / 1982 / 1978 / 1962$ & 4 & 17 & 11.25 & 0.394 & 18 & 11.5 & 0.386 & 19 & 11.75 & 0.378 \\
\hline 13 & 1990/1985/1978/ 1964 & 4 & 17 & 10.75 & 0.403 & 18 & 11 & 0.394 & 19 & 11.25 & 0.386 \\
\hline 14 & 1990/ 1985/ 1978/ 1964 & 4 & & & & 18 & 11 & 0.394 & & & \\
\hline 15 & $2003 / 1962$ & 2 & 4 & 22.5 & 0.522 & 5 & 23 & 0.471 & & & \\
\hline 16 & $2003 / 1962$ & 2 & & & & 5 & 23 & 0.471 & & & \\
\hline 17 & $2003 / 1982$ & 2 & 4 & 12.5 & 0.539 & 5 & 13 & 0.488 & & & \\
\hline 18 & $2003 / 1982$ & 2 & 4 & 12.5 & 0.539 & 5 & 13 & 0.488 & & & \\
\hline 19 & $2003 / 1982$ & 2 & & & & 5 & 13 & 0.488 & & & \\
\hline 20 & $2003 / 1990 / 1970$ & 3 & & & & 5 & 12.7 & 0.506 & & & \\
\hline 21 & $2003 / 1990 / 1970$ & 3 & & & & 5 & 12.7 & 0.506 & & & \\
\hline 22 & $2003 / 1990 / 1982 / 1959$ & 4 & 4 & 12 & 0.608 & 5 & 12.3 & 0.561 & 6 & 12.5 & 0.526 \\
\hline 23 & $2003 / 1990 / 1982 / 1959$ & 4 & 4 & 12 & 0.608 & 5 & 12.3 & 0.561 & 6 & 12.5 & 0.526 \\
\hline 24 & 2003/ 1990/ 1982/ 1959 & 4 & 4 & 12 & 0.608 & 5 & 12.3 & 0.561 & 6 & 12.5 & 0.526 \\
\hline 25 & $2007 / 1985 / 1970 / 1964$ & 4 & & & & & & & 2 & 11.8 & 0.768 \\
\hline 26 & $2007 / 1985 / 1970 / 1964$ & 4 & & & & & & & 2 & 11.8 & 0.768 \\
\hline 27 & $2007 / 1985 / 1978 / 1964$ & 4 & & & & & & & 2 & 11.8 & 0.772 \\
\hline
\end{tabular}

NF: Number of fire, TSF: Time since fire, MFI: Mean fire interval, WHI: Wildfire history index. 
Guénon R., Vennetier M., Dupuy N., Ziarelli F. and Gros R. (2011) Soil organic matter quality and microbial catabolic functions along a gradient of

Author-produced version of the final draft post-refeering

the original publication is available at www.elsevier.com/locate/issn/09291393 - doi:10.1016/j.apsoil.2011.01.004

Guénon, R. et al., Applied Soil Ecology (2011), doi:10.1016/j.apsoil.2011.01.004

\subsection{Wildfire history mapping, soil sampling and wildfire history index}

The burned surfaces were mapped using a series of aerial pictures spanning a 56-year period from 1950 to 2006 and public fire databases. This map was then used to choose twenty seven sampling plots. Each sampling plot (300-400 $\mathrm{m}^{2}$ in size) is characterised by homogenous vegetation structure and cork oak as a common species to all. All sampling plots were similar in elevation (60-360 a.s.1.), position in the slope (midslope), orientation (SW-SE) and geological parent material. Geographic location of the plots, together with soil and vegetation characteristics, is presented in Table 1. The sampling plots were selected to obtain a large range of wildfire history defined as the number of fires, the interval between each fire and the interval between the last fire and a given sampling date. The wildfire history parameters of each sampling plot are presented in Table 2.

Firstly, seventeen plots were sampled in January 2007 to study relationships between soil microbial activities, soil organic matter quality and fire frequency. Then, in February 2008, in January 2009 and finally in June 2009, three other sets of respectively 24,12 and 12 plots were sampled to assess the predictability of soil microbial properties by FT-NIR spectroscopy over a maximum range of wildfire history. For each plot, after removing the thin litter layer from the soil surface, five bulk soil subsamples of the surface layer $(0-5 \mathrm{~cm}$ depth), each $20 \times 20 \mathrm{~cm}$ in size, were randomly cored and pooled. The composite soil samples were sieved ( 2 $\mathrm{mm}$ mesh size), homogeneously mixed and kept at $4^{\circ} \mathrm{C}$ until analysed for microbial properties or air-dried prior ${ }^{13} \mathrm{C}$ NMR and FT-NIR analyses.

A Wildfire History Index (WHI) was required to analyse properly the relationships between wildfire parameters (i.e. number of fires, interval between fires and sampling time) and the recovery of soil properties. WHI was designed to include the number of fires, the time between the last fire and soil measurements, and the time interval between fires. WHI was also parameterised (i) to increase with the number of fires, (ii) to decrease with the time since the last fire and, more generally (iii) to give more weight to recent fires than to old fires. WHI was calculated for all soils (Table 2) according to the following equation:

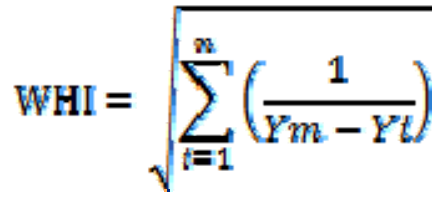

where $\mathrm{n}$ is the total number of fires, $\mathrm{Ym}$ is the sampling year and $\mathrm{Y}_{i}$ the year of $i$ th fire. The square root of this sum is applied to reduce the variability of the values for recent fires.

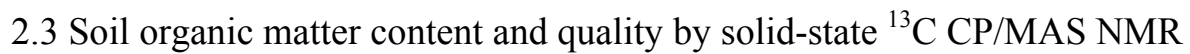

Organic matter content of soils collected in 2007 was obtained by loss on ignition $\left(16 \mathrm{~h}, 550^{\circ} \mathrm{C}\right)$. Prior to being analysed only for NMR, these soil samples were treated with a mixture of chlorhydric acid (1N) and fluorhydric acid (10\%) (v:v) using the procedure of Gélinas et al. (2001). This pre-treatment was used to suppress paramagnetic elements which interfere with the NMR signal. The solid-state ${ }^{13} \mathrm{C}$ NMR spectra were obtained on a Bruker Avance-400 MHz NMR spectrometer operating at a ${ }^{13} \mathrm{C}$ resonance frequency of 106 $\mathrm{MHz}$ and using a commercial Bruker double-bearing probe. About $100 \mathrm{mg}$ of samples were placed in zirconium dioxide rotors of 4-mm outer diameter and spun at the Magic Angle Spinning (MAS) rate of 10 kHz. The Cross Polarisation (CP) technique (Schaefer and Stejskal, 1976) was applied with a ramped ${ }^{1} \mathrm{H}-$ pulse starting at $100 \%$ power and decreasing to $50 \%$ during contact time $(2 \mathrm{~ms})$ in order to circumvent HartmannHahn mismatches (Cook et al., 1996). To improve resolution, a dipolar decoupling GT8 pulse sequence (Gerbaud et al., 2003) was applied during the acquisition time. The experiments were performed at ambient temperature and $20 \mathrm{~K}$ scans were accumulated using a delay of $2.5 \mathrm{~s}$, for an experimental time of $14 \mathrm{~h}$. The ${ }^{13} \mathrm{C}$ chemical shifts were referenced to tetramethylsilane and calibrated with glycine carbonyl signal, set at 176.5 ppm.

The ${ }^{13} \mathrm{C}$ NMR spectra were divided into 7 chemical shift regions according to Mathers et al. (2003): i.e. alkyl C (0-45 ppm), methoxyl C (45-60 ppm), $O$-alkyl C (60-92 ppm), di-O-alkyl C (92-112 ppm), aromatic C (112-142 ppm), phenolic C (142-160 ppm) and carboxyl C (160-185 ppm). In some instances, it was necessary to divide some chemical shift regions or sum certain peaks. The alkyl C region is characteristic of carbons in waxes and cutins, as well as aminoacid side-chain carbons (Forte et al., 2006). This region was divided into two areas: i.e. terminal methyl groups in short-chain methylene with a culminating peak at 25 $\mathrm{ppm}$ and $\mathrm{C}$ in long-chain polymethylene composed by 2 peaks $(30+33 \mathrm{ppm})$. The $O$-alkyl $\mathrm{C}$ region was composed by peaks (or shoulders) at 62 and $83 \mathrm{ppm}$ (C-6 and C-4 of amorphous cellulose) and peaks at 66 and $89 \mathrm{ppm}$ (C-6 and C-4 of crystalline cellulose) and the greatest peak at $73 \mathrm{ppm}$ assigned to cellulose $\left(\mathrm{C}_{3}\right.$ 
Guénon R., Vennetier M., Dupuy N., Ziarelli F. and Gros R. (2011) Soil organic matter quality and microbial catabolic functions along a gradient of

Author-produced version of the final draft post-refeering

the original publication is available at www.elsevier.com/locate/issn/09291393 - doi:10.1016/j.apsoil.2011.01.004

Guénon, R. et al., Applied Soil Ecology (2011), doi:10.1016/j.apsoil.2011.01.004

and $\mathrm{C}_{5}$ of hexoses), hemicellulose $\left(\mathrm{C}_{3}\right.$ and $\mathrm{C}_{5}$ of hexoses and $\mathrm{C}_{2}$ and $\mathrm{C}_{3}$ pentoses $)$ and lignin $\left(\mathrm{C}_{\alpha}, \mathrm{C}_{\beta}\right.$ and $\left.\mathrm{C}_{\gamma}\right)$ (Preston et al., 1997; Kögel-Knabner, 2002). The di-O-alkyl C region could be attributed to anomeric C-1 (Wilson et al., 1983) and also to C-2 of cycles and C-6 syringyl units (Hatcher, 1987). The aromatic C region composed of two peaks $(116+133 \mathrm{ppm})$ was fully conserved and attributed to lignin and also aromatic amino acid of protein, olefin and black carbon (Preston et al., 1997; DeLuca et al., 2006). The phenolic C region composed of two peaks (at 147 and $153 \mathrm{ppm}$ ) was conserved separately. The peak at $147 \mathrm{ppm}$ can be attributed to C-3 and C-4 of guaiacyl units of the lignin and the peak at $153 \mathrm{ppm}$ to C-3 and C-5 of syringyl units (Knicker et al., 2005). The Carboxyl C region was attributed to carboxyl and amide functions (Preston et al., 1997; Kögel-Knabner, 2002) present in tannins, hemicellulose, cutins, suberins and proteins (Forte et al., 2006).

A deconvolution of each spectrum was performed on DmFit (Massiot et al., 2002). Software Dmfit 2005 was used to determine the relative intensity of each selected region or peak (Massiot et al., 2002). The alkyl C / O-Alkyl C ratio was calculated as follow.

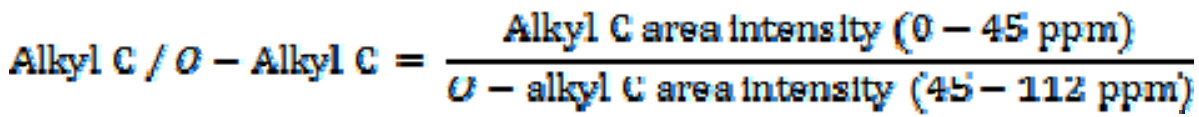

\subsection{Soil microbial properties}

The community-level physiological profiles (CLPPs) and microbial catabolic diversity were determined with BIOLOG ${ }^{\circledR}$ EcoPlates (BIOLOG Inc., Hayward, CA) using a procedure adapted from Garland and Mills (1991). We purposely did not adjust the inoculum as we considered the total microbial number as an inherent characteristic of microbial communities of each plot. Briefly, $5 \mathrm{~g}$ (dry weight equivalent) of sub-sample was added to $50 \mathrm{ml}$ of sterile $0.1 \%$ Na-pyrophosphate solution ( $\mathrm{pH} 7$ ), then shaken $(20 \mathrm{~min})$ and finally centrifuged $\left(500 \mathrm{~g}, 10 \mathrm{~min}, 4{ }^{\circ} \mathrm{C}\right)$ to obtain a microbial suspension. Exactly $1 \mathrm{ml}$ of supernatant was diluted into $99 \mathrm{ml}$ of sterile saline solution $(0.85 \% \mathrm{NaCl})$, hand-mixed for $30 \mathrm{sec}$. and left to stand for $10 \mathrm{~min}$. A $125 \mu \mathrm{l}$ aliquot of the diluted solution was added to each of 96 wells in a BIOLOG ${ }^{\circledR}$ EcoPlate. The plates were incubated at $25^{\circ} \mathrm{C}$ for 6 days and the absorbance was read three times a day (490 $\mathrm{nm}$ ) using a microplate reader (Metertech P960, Avantec, France). Microbial C-use intensity was assessed as the rate of average well colour development (AWCD) calculated as follows: AWCD $=\Sigma$ ODi/31, where ODi is the optical density for each well in the mid-exponential growth phase (i.e. after 72h). Absorbance values for the wells with $\mathrm{C}$ sources were blanked against the control well. The incubation time resulting in an AWCD = 0.5 absorbance unit $\left(\mathrm{T}_{0.5}\right)$ was calculated for each samples and used to standardise the optical density of each C-containing wells (Garland and Mills, 1991). Catabolic diversity (CD) was calculated using the reciprocal Simpson index 1/D (Simpson, 1949): $\mathrm{D}=\Sigma \mathrm{p}_{\mathrm{i}}{ }^{2}$, where $\mathrm{p}_{\mathrm{i}}$ is the relative AWCD of the $i^{\text {th }} \mathrm{C}$-substrate.

Basal respiration (BR) was measured to assess the ecophysiological state of microbial communities of soil samples collected in 2007, 2008 and $2009(\mathrm{~N}=65)$. Ten g (dry weight equivalent) of soil were placed in $117 \mathrm{ml}$ glass jars and then pre-incubated 4 days at $22^{\circ} \mathrm{C}$ to allow microbial respiration to restart. The glass jars were then closed with hermetic rubber septa, and incubated for 4 hours $\left(22^{\circ} \mathrm{C}\right)$. After incubation, $1 \mathrm{ml}$ of air was sampled in the head space with a syringe and injected into a gas chromatograph (Chrompack CHROM 3 $\mathrm{CP}$ 9001) to analyse $\mathrm{CO}_{2}$ production. The gas chromatograph was equipped with a thermal conductivity detector and a packed column (Porapack). The carrier gas helium flow was regulated at $60 \mathrm{ml} \mathrm{h}^{-1}$. Ambient $\mathrm{CO}_{2}$ concentrations were subtracted from sampled $\mathrm{CO}_{2}$ concentrations and resulting values were adjusted at $22^{\circ} \mathrm{C}$ according to Ideal Gas Laws using a $\mathrm{Q}_{10}=2$. Microbial biomass (MB) was estimated using substrateinduced respiration (SIR) rates (Anderson and Domsch, 1978). Ten grams (dry weight equivalent) of subsamples were placed in $117 \mathrm{ml}$ glass jars and amended with powdered glucose (1000 $\mu \mathrm{g} \mathrm{C} \mathrm{g}^{-1}$ soil). One ml of air was sampled in the head space with a syringe and injected into the gas chromatograph to analyse $\mathrm{CO}_{2}$ production (see above). SIR rates were converted into MB using equations given by Beare et al. (1990).

\subsection{Fourier Transform Near Infrared spectroscopy}

For each soil sample (N=65), Fourier Transform Near-Infrared (FT-NIR) spectra were recorded in reflectance with an integration sphere using a Nicolet Antaris spectrometer interfaced to a personal computer. All the spectra were computed at $4 \mathrm{~cm}^{-1}$ resolution between 4500 and $10000 \mathrm{~cm}^{-1}$ using the software Omnic 2.1. Co-addition of symmetrical interferograms on 100 scans was performed for each spectrum. Air was taken as reference for the background spectrum before each sample. NIR spectra depend on the number and type of chemical bonds such as $\mathrm{C}-\mathrm{H}, \mathrm{N}-\mathrm{H}, \mathrm{S}-\mathrm{H}, \mathrm{O}-\mathrm{H}$ and $\mathrm{C}=\mathrm{O}$ in the analysed material (Foley et al., 1998). The 
Guénon R., Vennetier M., Dupuy N., Ziarelli F. and Gros R. (2011) Soil organic matter quality and microbial catabolic functions along a gradient of

Author-produced version of the final draft post-refeering

the original publication is available at www.elsevier.com/locate/issn/09291393 - doi:10.1016/j.apsoil.2011.01.004 Guénon, R. et al., Applied Soil Ecology (2011), doi:10.1016/j.apsoil.2011.01.004

predictive ability of FT-NIR for microbial properties and fire regime parameters was performed by partial least squares regressions (PLSR) (Tenenhaus, 1998). One PLSR model was built for each dependent variable and using full spectra. To improve PLSR models, pretreatments such as multiplicative scatter correction (MSC), standard normal variate (SNV) or first derivative were applied to the FT-NIR spectra. Firstly, a set of 54 samples was randomly selected and used to establish the model of calibration. This model was constructed on a selection of the most relevant wavelengths obtained by the variable importance of the projection (VIP) method (Cécillon et al., 2008). The optimal factor number, $\mathrm{R}^{2}$ of calibration model, standard error of calibration (SECV) were computed by full cross validation. The standard errors of calibration and prediction (SECV and SEP) were analysed regarding to the standard errors of the measure (SEM). The response values of the 11 remaining samples were thus predicted using the calibration model. The evaluation of the prediction performance was estimated by the $\mathrm{R}^{2}$ of the prediction model, the standard error of prediction (SEP) and the residual predictive deviation (RPD). RPD is the ratio of the standard deviation of measured data to SEP.

\subsection{Statistical analysis}

Relationships between wildfire history index and microbial properties or ${ }^{13} \mathrm{C}$ NMR chemical functions of only soils sampled in January 2007 were analysed by linear and non-linear regression models (quadratic, inverse and piecewise) using respectively Statistica 6.0 or SegReg program (Oosterbaan, 1994). Model selection was based on the F-test criterion. Models with the greatest F-values are considered best-fit (Knell, 2009). Evidence for a threshold response (i.e. a discontinuity) in the changes in soil properties dependently on fire frequency requires the piecewise regression model to provide the best fit to the data (Radford et al. 2005). In this case, SegReg thus calculated an optimum breakpoint (i.e. with the smallest interval of confidence). Specific relationships between microbial activities and ${ }^{13} \mathrm{C}$ NMR chemical functions were tested using Pearson's correlation coefficients (Statistica 6.0).

We used redundancy analysis (RDA), a constrained form of PCA in which the explanatory axes are constrained to be linear combinations of the explanatory variables. Constrained ordination explicitly links two matrices: one dependent matrix and one explanatory matrix. Both are implied at the stage of the ordination. We used the non-parametric RDA rather than the parametric multivariate ANOVA, because the latter requires multivariate normality and homogeneity of covariance matrices and cannot be used when the number of CLPPs is greater than the number of plots. The RDA followed by a Monte Carlo permutation test (5000 random permutations) were used to determine the statistical significance of the relation between the CLPPs (i.e. dependent variables) and the chemical functions of soil organic matter (SOM) (i.e. explanatory variables). In addition, RDA gives marginal effects which show the variance explained by each environmental variable alone $(\lambda-1)$. RDA and Monte Carlo permutation tests were performed using CANOCO 4.5 (ter Braak and Smilauer, 2002).

\section{Results}

\subsection{Wildfire History Index (WHI) parameterisation and computation}

Figure 1 reports the results of simulations of WHI values by varying the date of the last wildfire event (d on abscissa axis) and using a fixed sampling date (i.e. 2007). A total of eighteen simulations were performed changing fire parameters such as the number of fires (Figure 1a), the intervals between fires (Figure 1b), and both number of fires and intervals (Figure 1c). WHI values, whatever the simulation, increased in an exponential way from recent wildfire (i.e. approximately from 2000). WHI values increased with fire number for each simulation with the same date of the last wildfire (d) (Figure 1a). WHI values for a last wildfire in 2000 are $0.35,0.40,0.43,0.46,0.48$ and 0.50 for respectively $1,2,3,4,5$ and 6 fires. Figure $1 \mathrm{a}$ also shows that WHI values can be higher with low number of fires than with high number of fires if the date of the last wildfire is recent. WHI values increase with the shorter fire interval for both simulations performed with 3 and 6 fires (Figure 1b). For the same date of the last fire, WHI values always increased with the number of fire and the decrease of fire interval (Figure 1c). Moreover, the WHI model emphasises more on the time since the last fire than on the fire intervals and the number of fires. The WHI model was thus used to calculate a value of fire frequency for each studied plot. The WHI values varied from 0.13 to 0.78 depending on wildfire history of each plot and sampling date (i.e. 2007, 2008 and 2009) (Table 2). 
Guénon R., Vennetier M., Dupuy N., Ziarelli F. and Gros R. (2011) Soil organic matter quality and microbial catabolic functions along a gradient of wildfire history in a Mediterranean ecosystem, Applied Soil Ecology 48 (1) 81-93

Author-produced version of the final draft post-refeering

the original publication is available at www.elsevier.com/locate/issn/09291393 - doi:10.1016/j.apsoil.2011.01.004

Guénon, R. et al., Applied Soil Ecology (2011), doi:10.1016/j.apsoil.2011.01.004

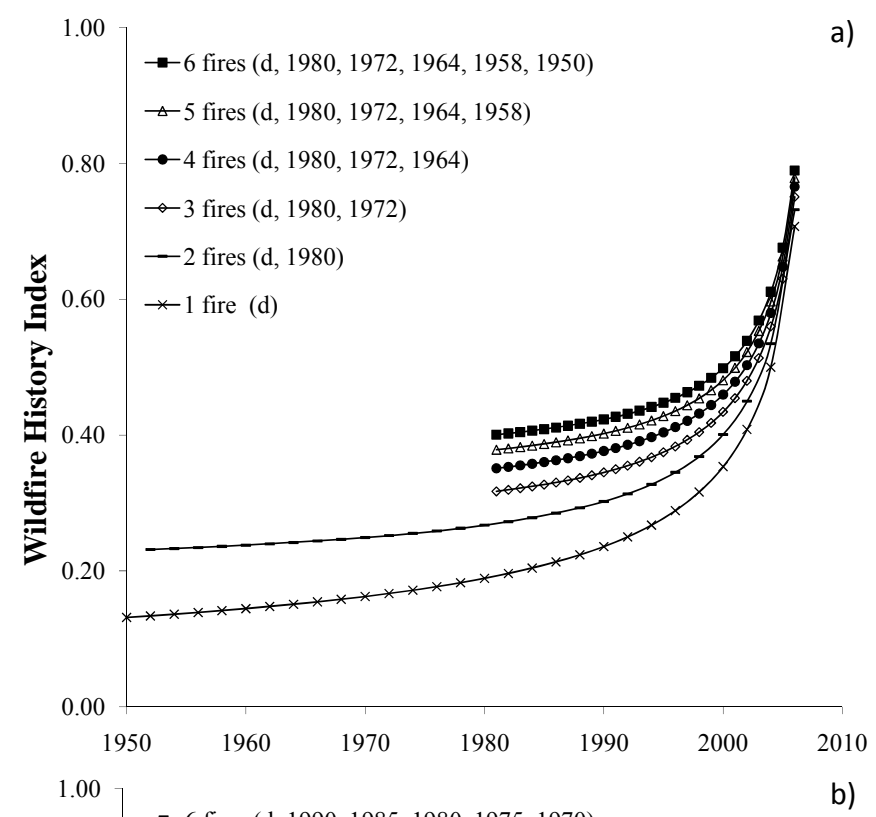

a)

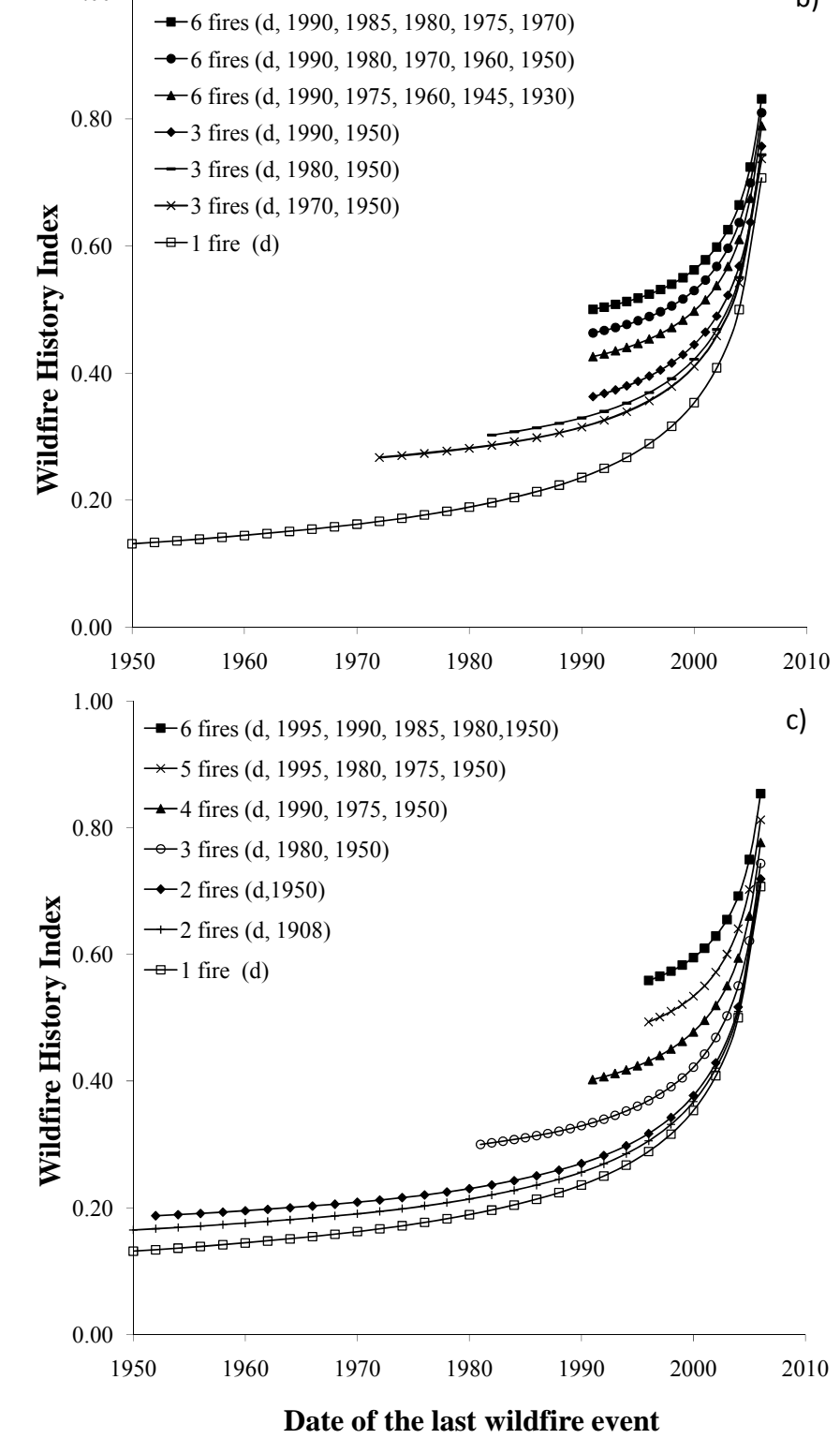


Guénon R., Vennetier M., Dupuy N., Ziarelli F. and Gros R. (2011) Soil organic matter quality and microbial catabolic functions along a gradient of wildfire history in a Mediterranean ecosystem, Applied Soil Ecology 48 (1) 81-93

Author-produced version of the final draft post-refeering

the original publication is available at www.elsevier.com/locate/issn/09291393 - doi:10.1016/j.apsoil.2011.01.004

Guénon, R. et al., Applied Soil Ecology (2011), doi:10.1016/j.apsoil.2011.01.004

Figure 1: Simulations in the wildfire history index values by a) an increase of the number of fires alone, b) a decrease of the fire interval alone, c) both number of fires and fire interval variations.
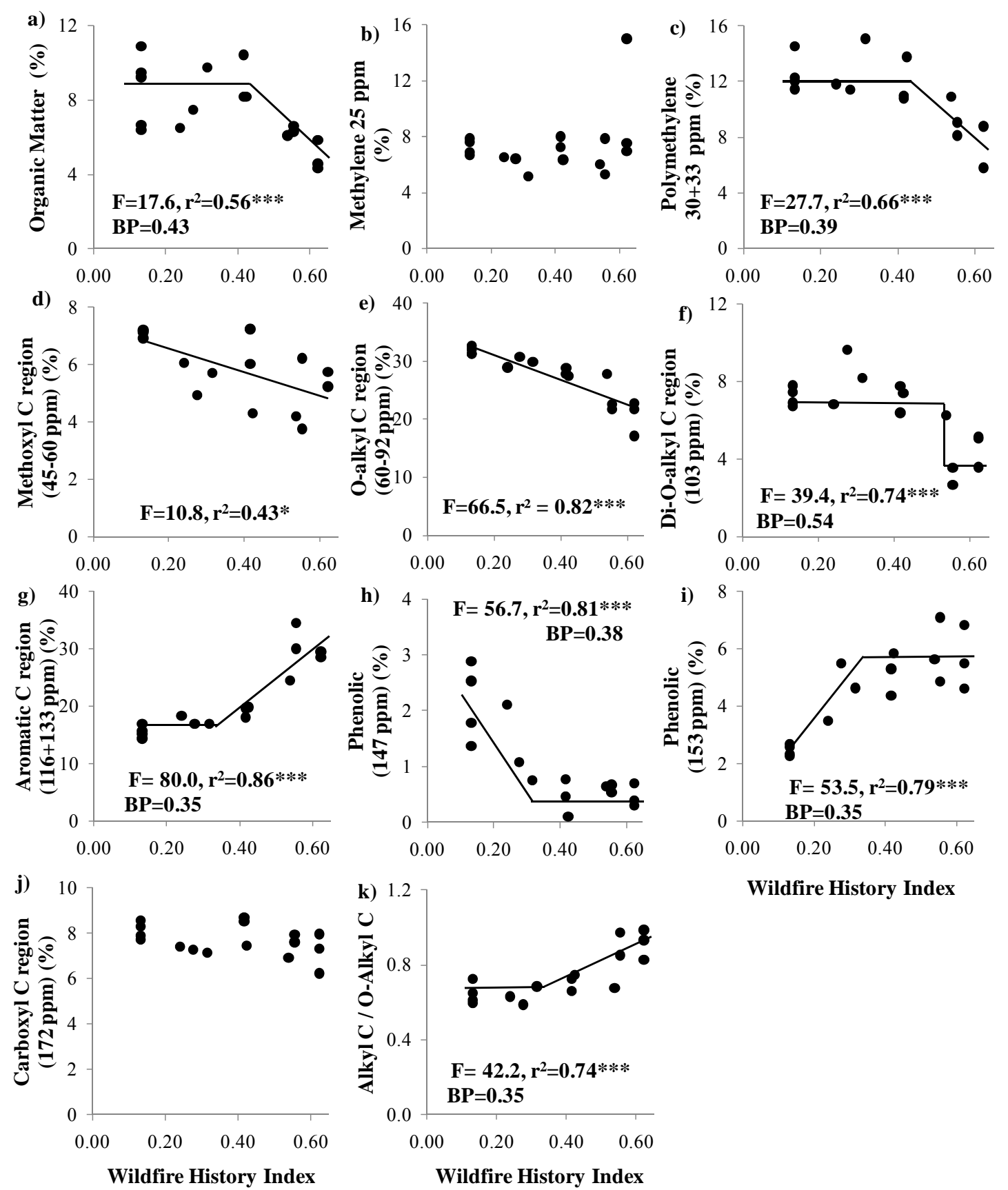

Figure 2: Soil organic matter content and relative intensity (\%) in the solid-state ${ }^{13} C N M R$ spectra in relation with wildfire history index. $F$ and $R^{2}$ values are reported for significant $(*, * *, * * *$ for respectively $P<0.05, P$ $<0.01$ and $P<0.001)$ linear and piecewise regressions $(N=17) . B P=$ breakpoint.

\subsection{Soil organic matter content and quality by solid state ${ }^{13} \mathrm{C}$-NMR spectroscopy}

Soil organic matter (SOM) content expressed on a mass basis in recently burned soils, was found significantly lower than both unburned soils since 1950 and 1990 (Figure 2 a). Soils that remained unburnt since at least 1950 displayed a distribution of chemical functions of organic matter in the following order $O$ Alkyl C (37\%) >Alkyl C (28\%) >Aromatic C (16\%) >Carboxyl C (8\%) > Methoxyl C (6\%) > Phenolic C (4\%). Linear and piecewise regressions were the best models found linking the relative intensity of specific chemical functions to the wildfire history index (WHI). Among the two subdivisions of Alkyl C region only methyl functions in polymethylene significantly decreased from a WHI breakpoint at $0.39\left(\mathrm{r}^{2}=0.66, \mathrm{p}<0.001\right)$ (Figure $2 \mathrm{c})$. Methoxyl $\mathrm{C}$ region $(45-60 \mathrm{ppm})$ presented a negative linear regression along WHI $\left(\mathrm{r}^{2}=0.43, \mathrm{p}<0.05\right)$ 
Guénon R., Vennetier M., Dupuy N., Ziarelli F. and Gros R. (2011) Soil organic matter quality and microbial catabolic functions along a gradient of wildfire history in a Mediterranean ecosystem, Applied Soil Ecology 48 (1) 81-93

Author-produced version of the final draft post-refeering

the original publication is available at www.elsevier.com/locate/issn/09291393 - doi:10.1016/j.apsoil.2011.01.004 Guénon, R. et al., Applied Soil Ecology (2011), doi:10.1016/j.apsoil.2011.01.004

(Figure 2d). The $O$-alkyl C region $(60-92 \mathrm{ppm})$ presented a negative linear regression along WHI $\left(\mathrm{r}^{2}=0.54\right.$, $\mathrm{p}<0.001)$ (Figure 2e). The piecewise regression computed on the di-O-alkyl C $(92-112 \mathrm{ppm})$ showed 2 constant lines separated by a breakpoint at WHI $=0.54\left(\mathrm{r}^{2}=0.74, \mathrm{p}<0.001\right)$ (Figure 2f). This breakpoint separated the relative intensities of di- $O$-alkyl C function of soils burned in 1990 (7\% in average) from those burned in 2003 (3\% in average). Aromatic $\mathrm{C}$ region (112-142 ppm), which accounted for $15 \%$ of the total intensity of ${ }^{13} \mathrm{C}$-NMR spectra for unburned soil, strongly increased from a breakpoint at WHI $=0.35$ until $30 \%$ for high fire frequencies $\left(\mathrm{r}^{2}=0.86, \mathrm{p}<0.001\right)$ (Figure $2 \mathrm{~g}$ ). The phenolic $\mathrm{C}$ peak at $147 \mathrm{ppm}$ showed a rapid decrease from the lowest WHI values until the breakpoint $(\mathrm{WHI}=0.38)$ beyond which this relative intensity became constant $\left(\mathrm{r}^{2}=0.81, \mathrm{p}<0.001\right)$ (Figure $2 \mathrm{~h}$ ). The other phenolic $\mathrm{C}$ peak at $153 \mathrm{ppm}$ showed an opposite trend but with a close breakpoint (WHI $=0.35, \mathrm{r}^{2}=0.79, \mathrm{p}<0.001$ ) (Figure 2i). Moreover, the relative intensities of these two peaks were similar for unburned soils and the strongest differences were recorded for high fire frequencies.

Alkyl $\mathrm{C}$ to $O$-alkyl $\mathrm{C}$ ratio was calculated to assess changes in organic matter quality in relation to the evolution of WHI. This ratio presented a significant increase $\left(r^{2}=0.65, p<0.001\right)$ from a breakpoint at $\mathrm{WHI}=0.35$ corresponding to an increase up to $44 \%$ (Figure $2 \mathrm{k}$ ).

\subsection{Soil microbial properties}

Linear or piecewise regressions were the best models found, linking microbial properties to wildfire history index (WHI). Figure 3 shows that the average well colour development (AWCD) was weakly correlated with WHI $\left(\mathrm{r}^{2}=0.22, \mathrm{p}<0.05\right)$, while microbial biomass $(\mathrm{MB})$ and catabolic diversity $(\mathrm{CD})$ presented a straightforward linear decrease along WHI $\left(\mathrm{r}^{2}=0.52, \mathrm{p}<0.01\right.$ and $\mathrm{r}^{2}=0.68, \mathrm{p}<0.001$ respectively). Basal respiration (BR) was better related to WHI with significant piecewise regression $\left(r^{2}=0.64, p<0.001\right)$ (Figure $3 \mathrm{c})$. From the breakpoint at $\mathrm{WHI}=0.42$, BR decreased more than $50 \%$.
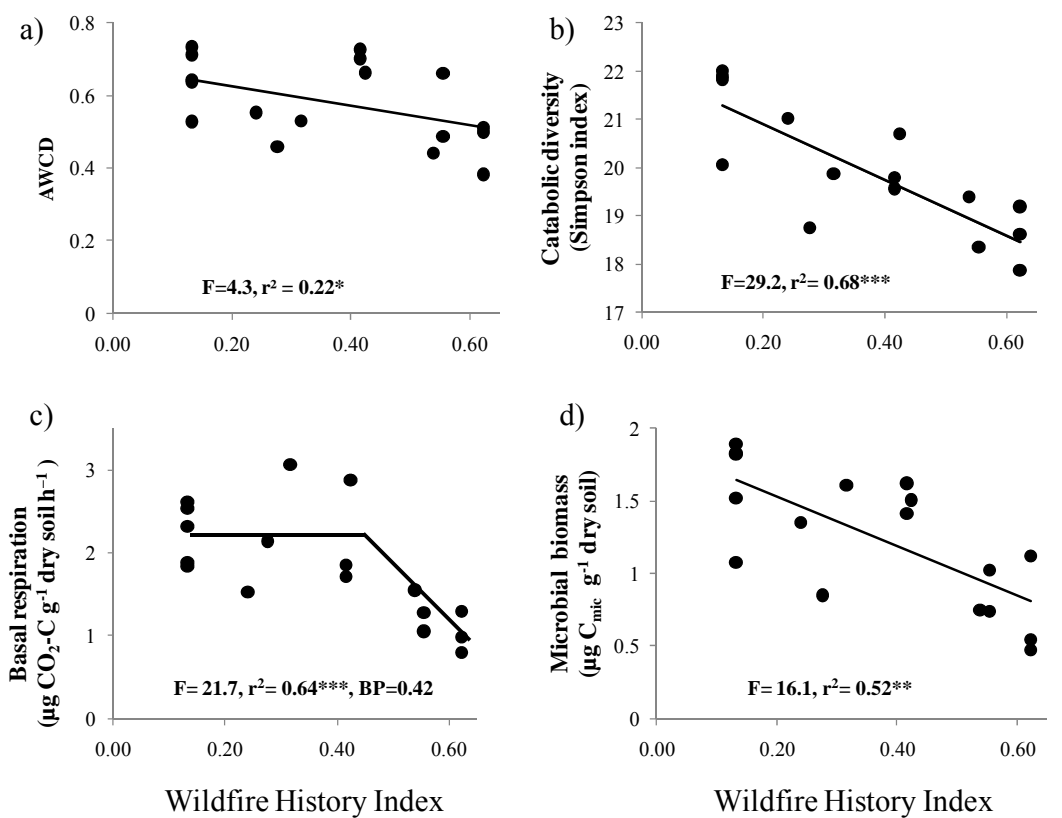

Figure 3: Average well colour development (a), microbial catabolic diversity (b), basal respiration (c) and biomass $(d)$ in relation with wildfire history index. $F$ and $R^{2}$ values are reported for significant $(*, * *, * * *$ for respectively $P<0.05$, $P<0.01$ and $P<0.001)$ linear and piecewise regressions $(N=17)$. $B P=$ breakpoint.

The first two axes of the RDA ordination tri-plot (Figure 4) explained 32.5\% of the total variance in the CLPPs data. Microbial CLPPs for the frequently burned soils (i.e. positive part of the RDA axis 1) were characterised by a high utilisation of $11 \mathrm{C}$-substrates (i.e. grey arrows) highly and positively correlated $(\mathrm{r}>0.5)$ to CA1 (bold grey arrows in Figure 4). These $11 \mathrm{C}$-substrates are carboxylic acids, carbohydrates, amines, amino acids and polymers. Among these $11 \mathrm{C}$-substrates, five are $\mathrm{N}$-containing substrates (i.e. L-Arginine, DGlucosaminic acid, L-Asparagine, Putrescine and L-Serine), 3 are complex substrates such as phenolic (i.e. 4hydroxybenzoic acid), 2 polymers and also 3 carbohydrates. However, only $5 \mathrm{C}$-substrates were highly and negatively correlated ( $r>0.5$ on CA1) with the ordination of lower fire frequencies (negative part of the RDA axis 1) including 4 substrates containing-glucose-molecule (i.e. $\beta$-methyl-D-glucoside, N-acetyl-Dglucosamine, D-cellobiose, glucose-1-phosphate). 
uénon R., Vennetier M., Dupuy N., Ziarelli F. and Gros R. (2011) Soil organic matter quality and microbial catabolic functions along a gradient of wildfire history in a Mediterranean ecosystem, Applied Soil Ecology 48 (1) 81-93

Author-produced version of the final draft post-refeering

the original publication is available at www.elsevier.com/locate/issn/09291393 - doi:10.1016/j.apsoil.2011.01.004

Guénon, R. et al., Applied Soil Ecology (2011), doi:10.1016/j.apsoil.2011.01.004

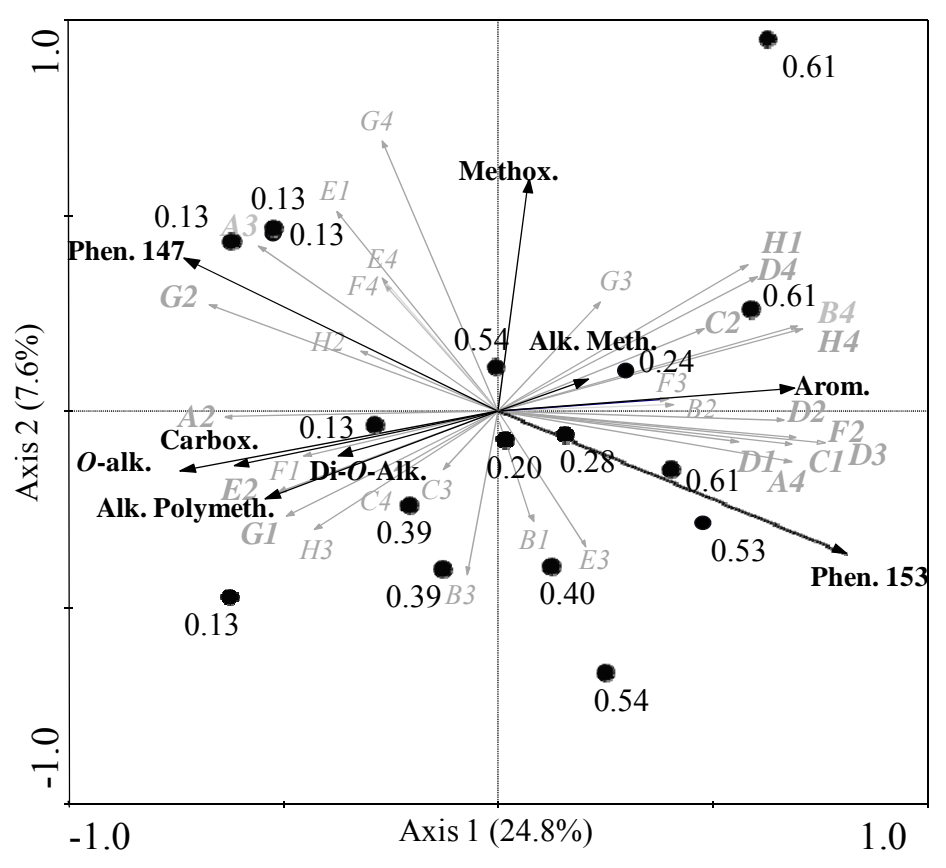

Figure 4: RDA tri-plot of microbial catabolic profiles of soils affected by various WHI (black circles), solid-state ${ }^{13}$ C NMR signals (black arrows) as explanatory variables and C-substrates (grey arrows). Alk. Meth.: alkyl $C$ in methylene; Alk. Polymeth.: alkyl $C$ in polymethylene; Methox.: methoxyl C, O-Alk.: O-Alkyl C; Di-O-Alk.: Di-O-alkyl C, Arom.: aromatic $C$, Phen. 147: phenolic $C$ at 147 ppm; Phen. 153: phenolic $C$ at 153 ppm; Carbox.: carboxyl C. A2: $\beta$-methyl-Dglucoside ; A3: D-galactonic acid $\gamma$-lactone; A4: L-arginine; B1: pyruvic acid methyl ester; B2: D-xylose; B3: D-galacturonic acid; B4: L-asparagine; $C 1$ : tween 40; $C 2: i$ erythritol; C3: 2-hydroxy benzoic acid; C4: L-phenylalanine; D1: tween 80; D2: Dmannitol; D3: 4-hydroxybenzoic acid; D4: L-Serine; E1: $\alpha$-cyclodextrin; E2: N-acetylD-glucosamine; E3: $\gamma$-hydroxybutyric acid ;

E4: L-threonine; F1: glycogen; F2: D-glucosaminic acid; F3: itaconic acid; F4: glycyl-L-glutamic acid; G1: D-cellobiose; G2: glucose-1-phosphate; G3: $\alpha$-ketobutyric acid; G4: phenylethyl amine; H1: $\alpha$-D-lactose; H2: D,L a-glycerol phosphate; H3: D-malic acid; H4: putrescine.

3.4 Relationships between soil microbial properties and soil organic matter quality (SOM)

Pearson's correlation coefficients between chemical functions of SOM and basal respiration (BR), microbial biomass (MB) and catabolic diversity (CD) are consigned in Table 3.

Table 3: Correlation coefficients ( $r$ values) between $N M R{ }^{13} C$ chemical functions of soil organic matter and microbial properties

\begin{tabular}{|c|c|c|c|c|}
\hline $\begin{array}{l}{ }^{13} \mathrm{C} \text { NMR signal } \\
\text { (Chemical shift in ppm) }\end{array}$ & AWCD & $\begin{array}{l}\text { Catabolic } \\
\text { diversity }\end{array}$ & $\begin{array}{l}\text { Basal } \\
\text { respiration }\end{array}$ & $\begin{array}{l}\text { Microbial } \\
\text { biomass }\end{array}$ \\
\hline Alkyl C region (0-45 ppm) & & & & \\
\hline Methylene 25 ppm & 0.13 & 0.08 & -0.25 & 0.09 \\
\hline Polymethylene $30+33 \mathrm{ppm}$ & 0.41 & $0.64 * *$ & $0.87 * * *$ & $0.74 * * *$ \\
\hline Methoxyl C region (45-60 ppm) & 0.41 & $0.55^{*}$ & 0.20 & $0.59^{*}$ \\
\hline$O-$ Alkyl C region (60-92 ppm) & 0.43 & $0.72 * * *$ & $0.75^{* * *}$ & $0.72 * * *$ \\
\hline Di-O-Alkyl C region (92-112 ppm) & 0.15 & $0.52 *$ & $0.71 * * *$ & 0.47 \\
\hline Aromatic C region (112-142 ppm) & -0.41 & $-0.72 * *$ & $-0.78 * * *$ & $-0.71 * * *$ \\
\hline \multicolumn{5}{|l|}{ Phenolic C region (142-160 ppm) } \\
\hline Phenolic $147 \mathrm{ppm}$ & 0.32 & $0.76^{* * *}$ & 0.31 & 0.47 \\
\hline Phenolic 153 ppm & -0.46 & $-0.74 * * *$ & -0.42 & $-0.61 * *$ \\
\hline Carboxyl $\mathrm{C}$ region & $0.72 * * *$ & 0.35 & 0.13 & $0.52 *$ \\
\hline Alkyl C / $O-$ Alkyl C ratio & -0.34 & $-0.71 * *$ & $-0.63 * *$ & $-0.59 *$ \\
\hline
\end{tabular}

In the Alkyl C region (0-45 ppm), only the methyl functions in polymethylene $(30+33 \mathrm{ppm})$ were strongly and positively correlated to $\mathrm{BR}, \mathrm{MB}$ and $\mathrm{CD}(\mathrm{P}<0.001)$. Similar correlations were recorded between 
Guénon R., Vennetier M., Dupuy N., Ziarelli F. and Gros R. (2011) Soil organic matter quality and microbial catabolic functions along a gradient of

Author-produced version of the final draft post-refeering

the original publication is available at www.elsevier.com/locate/issn/09291393 - doi:10.1016/j.apsoil.2011.01.004 Guénon, R. et al., Applied Soil Ecology (2011), doi:10.1016/j.apsoil.2011.01.004

these microbial properties and the $O$-alkyl $\mathrm{C}$ region. On the other side, both aromatic (112-142 ppm) and phenolic (153 ppm) chemical functions were negatively correlated to microbial properties. Surprisingly, CD decreased concomitantly ( $p<0.001$ and $p<0.01$ respectively) to the phenolic peak at $147 \mathrm{ppm}$. Nevertheless, the decrease in SOM quality (i.e. increase in Alkyl C / O-Alkyl C ratio) was significantly correlated to a decrease in microbial properties (Table 3 ).

The first two axes of the RDA ordination tri-plot (Figure 4) accounted for $51.8 \%$ of the variance of the CLPPs-SOM relation. The correlations between the CLPPs and SOM on the RDA axis 1 and RDA axis 2 were $\mathrm{r}=0.97$ and $\mathrm{r}=0.99$, respectively. RDA and Monte Carlo permutation test showed that 5 of the 9 chemical functions of SOM (listed in order of decreasing importance) were significantly correlated to CLPPs (marginal effects $\lambda$-1) : i.e. phenolic C $147(\lambda-1=0.19, \mathrm{p}=0.002)$, phenolic C $153(\lambda-1=0.16, \mathrm{P}=0.008), O$-Alkyl C $(\lambda$ $1=0.16, p=0.006)$, aromatic $\mathrm{C}(\lambda-1=0.14, \mathrm{p}=0.001)$, carboxyl $\mathrm{C}(\lambda-1=0.12, \mathrm{p}=0.028)$ and methyl $\mathrm{C}$ in polymethylene $(\lambda-1=0.1, p=0.05)$. The ordination tri-plot showed that microbial CLPPs of soils frequently burned (i.e. in the positive part of axis 1) were associated with an increase in aromatic $\mathrm{C}$ and phenolic $\mathrm{C}$ at $153 \mathrm{ppm}$. CLPPs of soils infrequently burned (i.e.in the negative part of axis 1) were correlated with higher relative intensities of all other chemical functions which contributed significantly to the canonical axes (i.e. $O$ Alkyl C, methyl C in polymethylene, phenolic $\mathrm{C}$ at $153 \mathrm{ppm}$ and carboxyl C).

\subsection{Predictability of microbial properties and wildfire parameters by FT-NIR spectroscopy}

Predictability of microbial properties (i.e. basal respiration, microbial biomass, catabolic diversity) and wildfire parameters (i.e. wildfire history index, fire number, time since fire and mean fire interval) by FT-NIR spectroscopy was performed by PLSR using 65 soils samples. Table 4 highlights for each microbial property and wildfire parameter, the mean, the range and the standard deviation for all 65 soil samples. The high SD values were high due to the wide range of wildfire history and of the three sampling years. The factor number used for prediction, $\mathrm{R}^{2}$ associated to SECV and SEP, RPD and the bias values from PLSR are consigned in Table 5 .

Table 4: variability of microbial variables and fire parameters $(N=65)$

\begin{tabular}{|c|c|c|c|}
\hline & Mean & Minimum & Maximum \\
\hline \multicolumn{4}{|l|}{ Microbial properties } \\
\hline AWCD (unit of O.D.) & 0.66 & 0.31 & 1.33 \\
\hline Catabolic diversity & 17.18 & 14.04 & 21.53 \\
\hline Basal respiration $\left(\mu \mathrm{g} \mathrm{CO}_{2}-\mathrm{C} \mathrm{g}^{-1}\right.$ dry soil $\left.\mathrm{h}^{-1}\right)$ & 2.80 & 0.79 & 5.91 \\
\hline Microbial biomass $\left(\mu \mathrm{g} \mathrm{C}_{\mathrm{mic}} \mathrm{g}^{-1}\right.$ dry soil) & 1.70 & 0.47 & 3.19 \\
\hline \multicolumn{4}{|l|}{ Wildfire parameters } \\
\hline Wildfire history index & 0.41 & 0.13 & 0.78 \\
\hline Number of fire & 2.60 & 1.00 & 4.00 \\
\hline Time since fire (year) & 22.23 & 2.00 & 59.00 \\
\hline Mean fire interval (year) & 25.53 & 10.75 & 59.00 \\
\hline
\end{tabular}

Table 5: Prediction of microbial properties and wildfire parameters

\begin{tabular}{|c|c|c|c|c|c|c|c|c|}
\hline & \multirow[b]{2}{*}{ SEM } & \multicolumn{3}{|c|}{ Calibration $(n=54)$} & \multicolumn{4}{|c|}{ Prediction $(n=11)$} \\
\hline & & $\mathrm{F}$ & $\mathrm{R}^{2}$ & SECV & $\mathrm{R}^{2}$ & SEP & RPD & Bias \\
\hline \multicolumn{9}{|l|}{ Microbial properties } \\
\hline AWCD & 0.20 & 4 & 0.86 & 0.17 & 0.88 & 0.17 & 2.14 & -0.013 \\
\hline Catabolic diversity & 0.58 & 3 & 0.83 & 1.05 & 0.82 & 0.95 & 1.98 & -0.21 \\
\hline Basal respiration & 0.68 & 7 & 0.92 & 0.49 & 0.84 & 0.62 & 1.80 & 0.53 \\
\hline Microbial biomass & 0.25 & 5 & 0.86 & 0.32 & 0.87 & 0.38 & 1.83 & 0.11 \\
\hline \multicolumn{9}{|l|}{ Wildfire parameters } \\
\hline Wildfire history index & - & 8 & 0.91 & 0.086 & 0.95 & 0.070 & 3.72 & 0.0052 \\
\hline Fire number & - & 10 & 0.90 & 0.56 & 0.85 & 0.71 & 1.85 & 0.021 \\
\hline Time since fire & - & 6 & 0.93 & 8.49 & 0.97 & 6.18 & 3.76 & 0.021 \\
\hline Mean fire interval & - & 8 & 0.91 & 7.86 & 0.96 & 6.10 & 2.82 & 1.625 \\
\hline
\end{tabular}

AWCD: average well colour development; SEM: Standard error of the method; F: factor number; SECV:

Standard error of cross validation; SEP: Standard error of prediction; RPD: Residual predictive deviation. 
Guénon R., Vennetier M., Dupuy N., Ziarelli F. and Gros R. (2011) Soil organic matter quality and microbial catabolic functions along a gradient of

Author-produced version of the final draft post-refeering

the original publication is available at www.elsevier.com/locate/issn/09291393 - doi:10.1016/j.apsoil.2011.01.004

Guénon, R. et al., Applied Soil Ecology (2011), doi:10.1016/j.apsoil.2011.01.004

For microbial properties, the best result was achieved for AWCD $\left(\mathrm{R}^{2}\right.$ of prediction $=0.88 ; \mathrm{RPD}=2.14$; $\mathrm{SEP}=0.17$ units of optical density). Basal respiration (BR), microbial biomass (MB) and catabolic diversity (CD) with $\mathrm{R}^{2}>0.8$ in calibration and prediction and with RPD values comprised between 1.8 and 2, are considered as satisfactory and improvable predictions. Moreover, the range of SECV values was in agreement with the ranges of SEM and SEP, which provided an indication of the robustness of these microbial properties calibration (Table 5). The prediction was the more accurate for wildfire history index $\left(\mathrm{R}^{2}=0.95, \mathrm{RPD}=3.72\right)$ with a low error of prediction ( $\mathrm{SEP}=0.07$ ). Moreover, good prediction parameters were also obtained for the time since fire $\left(\mathrm{R}^{2}=0.97, \mathrm{RPD}=3.76\right)$ and the mean fire interval $\left(\mathrm{R}^{2}=0.96, \mathrm{RPD}=2.82\right)$ but with predictive errors (SEP) close to 6 years. Prediction model of fire number was less accurate $\left(\mathrm{R}^{2}=0.85\right)$ but nevertheless with a lower predictive error than 1 fire.

\section{Discussion}

\subsection{Wildfire history index}

Fires are characterised by their intensity, the frequency and also the season in which they occur, their spatial pattern or extent, and their type. Combined, these attributes describe the fire regime (Gill, 1975). According to Merrill and Alexander (1987), fire frequency is the average number of fires that occur per unit of time at a given point. Fire history is the chronological record of the occurrence of fire in an ecosystem and the main parameters of fire history are number of events, time since the last fire and fire intervals. Considering this definition, fire frequency does not allow to assess the effects of wildfire history on soil properties alone. Reich et al. (2001) proposed a fire frequency index based on the fire number over different periods and assessed the effect of increasing prescribed-fire frequency on soil nitrogen cycling. We previously proposed a fire recurrence index to model these fire parameters (Vergnoux et al., 2008). However, if we consider two different regimes in number of fires, this index, assigning different ranks for a common date of fire, will give more weight to this event into the more frequent fire regime. Moreover, this index gives too weight on old fires. Here, the wildfire history index (WHI) was developed in order to display, at a given point, a single numerical value representative of the different wildfire history parameters, and thus the random position of each fire event over the studied period that affects the soils properties and their recovery. The WHI was parameterised to increase with the number of fires, with the shortening of the time since the last fire and to give more weight to recent fires than to old fires. Moreover, the WHI model emphasises more on the time since the last fire than on the fire intervals and the number of fires. The exponential increase in WHI thus takes into consideration grievousness of the impact of recent fires on soil biochemical and biological properties (Pietro-Fernández et al., 1998). Moreover, the closer fires from each other's and the closer to the sampling date they occur, the higher WHI values will be. In another word, if 2 fires occurred within a period of 57 years and just before the sampling date, they may have had a stronger effect on a microbial property and its recovery than 4 fires over a period of 57 years with just one fire before the same sampling date. The WHI is able to take into account the sensitivity of SOM quality and microbiological properties of repeated fires in near fire intervals and more especially when fires are recent (Hatten et al., 2008). Trends in recovery of soil properties along fire frequency were mainly studied with prescribed fires (Reich et al., 2001; Boerner and Brinkman, 2003; Campbell et al., 2008). However, prescribed fires are generally conducted using regular events and within the limits of a fire plan that describes both the acceptable range of weather, moisture, fuel, and fire behaviour parameters to achieve the desired effects. Trends in recovery of soil quality, described after repeated but constant fire history, cannot be accurately extrapolated to the increase of wildfires frequency partly because of the stochastic chronology of wildfire history and of the lower intensity of prescribed fires.

\subsection{Changes in SOM content and chemical functions along WHI}

Four years after fires, the loss of SOM content ranging from $25 \%$ to $50 \%$ is in accordance with the results of Fernández et al. (1997), whereas other works have detected an increase in C content with low fire intensities (Santín et al., 2008; Knicker et al., 2005) due to input of partly charred material or litter from decaying trees. Seventeen years after fires, SOM content fully recovered whatever the number of fires. Jonhson and Curtis (2001) suggested that the recovery in SOM content, at long term, could result from organic matter sequestration by polyvalent soil cations, transformation of fresh organic material into recalcitrant forms and also nitrogen inputs from $\mathrm{N}$-fixer species. In the Maures Mountain ranges, the N-fixer Calycotome spinosa, a dominant species of burned areas (Table 1) could have increased soil $\mathrm{N}$ content and facilitated C sequestration (Paul and Clark, 1989). Moreover, fires could have increased bulk density of the 
Guénon R., Vennetier M., Dupuy N., Ziarelli F. and Gros R. (2011) Soil organic matter quality and microbial catabolic functions along a gradient of

Author-produced version of the final draft post-refeering

the original publication is available at www.elsevier.com/locate/issn/09291393 - doi:10.1016/j.apsoil.2011.01.004

Guénon, R. et al., Applied Soil Ecology (2011), doi:10.1016/j.apsoil.2011.01.004

topsoil (Giovannini et al., 1988) and thus further studies should analyse the effects of wildfire on C stock by expressing SOM on volume basis.

Unburned soils since at least 57 years (i.e. with the lowest WHI values) showed the usual spectra of poor humified SOM, in which the $O$-alkyl C signals representing carbohydrates but also side chains of lignin (Knicker et al., 2005) accounted for the greatest proportion (Santin et al., 2008). Another important region was the one between 0 and $45 \mathrm{ppm}$ (peaks at 25 and $30+33 \mathrm{ppm}$ ) contributing to $19 \%$ of the spectra intensity and attributable mainly to alkyl $\mathrm{C}$ in lipids, plants waxes, cutans and suberans. The alkyl $\mathrm{C} / O$-alkyl $\mathrm{C}$ ratio was in the range of usual values for unburned Mediterranean soils (Gonzalèz-Vila et al., 2002; Knicker et al., 2005; Certini et al., 2007) and also indicated a low degree of decomposition of SOM (Webster et al., 2001). Our results showed a low relative intensity of aromatic structures (112-165 ppm) close to $20 \%$. The aromatic $\mathrm{C}$ region (112-142 ppm) was the main contributor to this low aromaticity and could be attributed to lignin or products of lignin degradation, aromatic amino acids of proteins and black carbon at $133 \mathrm{ppm}$ (Preston et al., 1997; Skjemstad et al., 1999).

Fires were found to remove external oxygen groups of organic compounds, to reduce the chain length of alkyl compounds (Eckmeier and Wiesenberg, 2009) and to converse amide- $\mathrm{N}$ into heterocyclic $\mathrm{N}$ compounds (González-Pérez et al., 2004). These authors also reported common transformations such as aromatisation of sugars and lipids, macromolecular condensation of humic substances and production of black carbon. In this study, frequent wildfires resulted four years after the last fire (i.e. highest WHI values) in the formation of condensed and presumably refractory material, which increased the intensity of aromatic $\mathrm{C}$ region (112-142 ppm) at the expenses of the alkyl C, $O$-Alkyl C, Di- $O$-alkyl C signals. Similar alterations of SOM quality were observed by González-Vila et al. (2002) two years after a fire. Santin et al. (2008) stated that a lower alkyl $\mathrm{C} / O$-alkyl $\mathrm{C}$ ratio could reflect a slowing down in decomposition process after fire and thus a higher $O$-alkyl C intensity in burned soils. On the other side, we measured an increase in alkyl C / $O$-alkyl C ratio after fire. Guinto et al. (1999) showed similar results and stated that this increase revealed a preferential denaturation of carbohydrate relative to waxes and cutins, and could in turn slow down mineralisation rate. The phenolic $\mathrm{C}$ region is characterised by two peaks at 147 and $153 \mathrm{ppm}$, each assigned respectively to guaiacyl and syringyl lignin units (Preston et al., 1997; Kögel-Knabner, 2002). Condensed tannins also occur in at $153 \mathrm{ppm}$ as well as pyrolysis products (Knicker, 2007). These two peaks show different responses to burning with a decrease of the peak at $147 \mathrm{ppm}$ and an increase of the peak at $153 \mathrm{ppm}$, four years after fire. Preston et al. (1997) reported, for hardwood litter, that a split peak at $147 / 153 \mathrm{ppm}$ implies a large contribution of tannins in addition to lignin. Overall, the decrease in methoxyl signal concomitant with the decrease of the phenolic $\mathrm{C}$ peak at $147 \mathrm{ppm}$ confirms that fire resulted in a decrease of lignin content or byproducts. Moreover, we assume that the increase of the peak at $153 \mathrm{ppm}$ could result from toxic furans and pyranones formed during the charring of carbohydrates (Knicker, 2007) and also from condensed tannins brought by plant litter. In Mediterranean ecosystems, wildfires lead to the establishment of shrub communities, which are often close to monospecific stands of Cistus sp. (Castells et al., 2004, Curt et al., 2009). The litter of these pyrophyte species is characterised by high condensed tannins content (Castells et al., 2004).

The recoveries at short and long term in intensity of both methoxyl $\mathrm{C}$ region and $O$-alkyl $\mathrm{C}$ region were not affected by the number of fire as evidenced by their linear relationships with WHI. However, our study also confirms our initial hypothesis that some chemical functions of SOM can be in equilibrium with wildfire history. Indeed we provided strong evidence for thresholds in the recovery of four NMR signals and alkyl $\mathrm{C} / O$-alkyl $\mathrm{C}$ ratio. Recovery in SOM of burned areas depends on quantity and quality of litter inputs, but also on the rate of decomposition by soil heterotrophic microorganisms (Baldock et al., 1997). Relative intensity of polymethylene structures in alkyl $\mathrm{C}$ region increased between 4 and 17 years after fires. These structures are considered as particularly recalcitrant form of soil C (Baldock et al., 2004). Moreover, hydrophobicity of these structures, as well as their adsorption on clay surfaces can also explain their accumulation at long term. The positive relationship between alkyl $\mathrm{C}$ and microbial parameters may indicate that microbial decomposition did not limit the recovery of aliphatic compounds. In the decomposition process, the labile carbohydrates and proteins are the first decomposed compounds after simple monomers such as glucose and amino acids (Lützow et al., 2006) whereas the relative proportion of more stable compounds, such as lipids and waxes, increase (Derenne and Largeau, 2001). In our study, both SOM content and microbial basal respiration (see section 4.3) recovered 17 years after infrequent and frequent fire regimes. Therefore the progressive increase in relative intensity of labile carbohydrate-derived structures suggests that the decomposition process could be limited by the poor nutrient availability (Rutigliano et al., 2004) but not by the SOM content nor by the 
Guénon R., Vennetier M., Dupuy N., Ziarelli F. and Gros R. (2011) Soil organic matter quality and microbial catabolic functions along a gradient of wildfire history in a Mediterranean ecosystem, Applied Soil Ecology 48 (1) 81-93

Author-produced version of the final draft post-refeering

the original publication is available at www.elsevier.com/locate/issn/09291393 - doi:10.1016/j.apsoil.2011.01.004 Guénon, R. et al., Applied Soil Ecology (2011), doi:10.1016/j.apsoil.2011.01.004

microbial physiological status. Frequent fires were found to maintain high relative intensity of phenolic C peak attributed to condensed tannins probably by controlling plant communities and thus the quality of organic matter inputs. In the Maures mountain ranges, recurrent wildfires favour the expansion of shrublands (especially Cistus communities) (Curt et al., 2009) which produce high amounts of leaf secondary metabolites, including phenolic compounds (Gershenzon, 1984). Moreover, frequent fires were found to slow down the recovery in relative intensity of alkyl C of long-chain polymethylene. Curt et al (2009) also reported that dense coverage of Cistus species threatens the maintenance of cork and evergreen oak populations in the long term. The slowing down in the recovery of alkyl $\mathrm{C}$ signal intensity could thus result from a decrease in input of cuticular material including waxes, cutin and suberin, which is abundant for all Oak species of Mediterranean forests (Martins et al., 1999). Moreover, frequent fires could also have reduced the microbial synthesis of alkyl C compounds at the long term. Hopkins et al. (1997) reported that the enrichment of aliphatic carbons may be caused by the biosynthesis mediated by the soil microorganisms. Additionally, Knicker (2004) showed that there are indications for the apparent stabilisation of labile compounds, produced by microbial resynthesis and biomass recycling, because old OM contains large amounts of microbial polysaccharides and proteins. Previous studies employing solid-state ${ }^{13} \mathrm{C}$ NMR technique indicated an increase in aliphatic compounds concomitantly with humification (Baldock et al., 1997), so the lasting low relative intensity of phenolic $\mathrm{C}$ peak assigned guaiacyl unit of lignin or by-products after frequent fires is consistent with our hypothesis. Regarding the trend in recovery of aromatic $C$ region (112-142 ppm), we found that the recalcitrant char material did not remain 17 years after fire. These aromatic compounds could have been oxidised during decomposition leading to an increase in carboxyl C content (Knicker et al., 2006). However, the intensity of carboxyl C signal was not significantly affected by our fire histories. Therefore, other plausible explanations are that recovery of the relative intensity of aromatic structures with time could result from a loss of the black carbon through either erosion process (Rumpel et al., 2006) or through its chemical or biochemical oxidation (Cheng et al., 2006; Hilscher et al., 2009).

\subsection{Changes in soil microbial properties along WHI and drivers}

We found that both C-use intensity (i.e. average well colour development) and catabolic diversity have been reduced 4 years after infrequent and frequent fires. Contrary to Bergner et al. (2004), the BIOLOG ${ }^{\circledR}$ system was successful in relating C-use intensity and catabolic diversity to wildfire history. This difference could be due to the low frequency of the burnings events studied by Bergner et al. (2004). Our findings are however consistent with those of Campbell et al. (2008) but restricted to fast growing communities that can be cultivated in microplate conditions. In Biolog system, colour development was correlated with inoculum density and cellular respiration (Garland and Mills, 1991). Both soil microbial biomass and basal respiration were reduced 4 years after fires and thus could have resulted in the decrease in C-use intensity at short term.

In our study, catabolic diversity depended on both richness and evenness of the use of substrates (Degens et al., 2000). Richness, which is the number of C-substrate oxidised by the microbial community, was not affected by the wildfire history (data not shown). Therefore, the decrease in catabolic diversity can be attributed to a decrease in catabolic evenness (i.e. increase in the variability of substrates C-use by microbial community). A reduction in catabolic evenness was also found by D'Ascoli et al. (2005) in similar Mediterranean bioclimatic context but after single fire and controlled intensity. The RDA tri-plot (Figure 4) showed that microbial community used more intensively a great number of some C-substrates, reflecting the lower catabolic evenness when WHI increased. These substrates consisted in some N-containing and complex substrates such as aromatic and polymers. Our previous work reported a decrease in nitrate contents in recently burned soils (Guénon et al., submitted). Concomitantly with the low nitrate contents, the high SOM aromaticity could have increase microbial demand in nitrogen resulting in a preferential utilisation of some substrates such as N-containing compounds. Indeed, Orwin et al. (2006) reported that the addition of complex compounds to a grassland soil increased the use of N-containing amino acids. They concluded that more enzymes were required for the decomposition of complex $\mathrm{C}$ compounds, which resulted in greater microbial $\mathrm{N}$ demand. Moreover recent wildfires dramatically increased aromaticity of SOM and could have favoured a strong capability of microbial community to oxidise aromatic compounds and polymers. The recovery in microbial catabolic profiles was related to the quality of SOM. Indeed, Monte Carlo permutation test confirmed that chemical functions of SOM, especially for $O$-alkyl C, aromatic $\mathrm{C}$ and phenolic $\mathrm{C}$, were related to the ordination of C-substrate utilisation profiles. Our results support those of Degens et al. (2000) in that soil managements that resulted in lower SOM content, and also, in alteration of SOM quality consisting in a loss in readily decomposable organic $\mathrm{C}$ fractions, tended to result in lower catabolic evenness. Pietikainen et 
Guénon R., Vennetier M., Dupuy N., Ziarelli F. and Gros R. (2011) Soil organic matter quality and microbial catabolic functions along a gradient of wildfire history in a Mediterranean ecosystem, Applied Soil Ecology 48 (1) 81-93

Author-produced version of the final draft post-refeering

the original publication is available at www.elsevier.com/locate/issn/09291393 - doi:10.1016/j.apsoil.2011.01.004 Guénon, R. et al., Applied Soil Ecology (2011), doi:10.1016/j.apsoil.2011.01.004

al. (2000) also reported change in catabolic profiles after short term heating of dry forest humus which they explained by the change in quality of SOM. The labile organic fractions support a significant proportion of the heterotrophic microbial biomass (Chotte et al., 1998), and their loss after fire could decrease microbial catabolic evenness through disproportionate decline or enhancement in some catabolic functions. The decline in catabolic evenness could result in a less resistant decomposition function (Degens et al., 2000). If this is the case, then fire histories such as recent or close fires, resulting in substantial losses or alterations of SOM will generate a more vulnerable soil system to recurrent Mediterranean stresses such as drought and heat-waves.

The contributions of $O$-alkyl C to the ordination of catabolic profiles and the correlations with AWCD and catabolic diversity allowed us to suspect that changes in the more readily decomposable compounds have strong significance for recovery in microbial catabolic capabilities. The progressive recovery in decomposable fraction through vegetation inputs of fresh organic matter could have promoted an increase in microbial diversity, as stress-tolerating r-selected micro-organisms could co-exist with competitive K-selected species (Grime, 1979), and thus increased the catabolic evenness (Schipper et al., 2001). Our results would support the Grime's (1979) intermediate disturbance hypothesis that predicts greatest diversity and evenness at intermediate level of disturbance. However we did not measure any decline in catabolic evenness at the higher levels of decomposable SOM. Therefore, we hypothesised that a fire history without burning event since 57 years at least could be an intermediate disturbance regime for the Mediterranean ecosystems.

\subsection{Predictions by FT-NIR spectroscopy}

Our study was the first attempt of quantitative prediction with FT-NIR of both the recovery of soil microbial properties at short and long term after fire and fire history parameters resulting in specific trends in recovery of these microbial properties. The calibration and prediction sets comprised respectively 54 and 11 samples collected in 4 times from January 2007 to June 2009.

Our results showed that information contained in near-infrared soil spectra can be used to predict the recovery of soil microbial properties. They confirm other works that successfully used NIR spectroscopy to predict soil biological properties (Cécillon et al., 2008), specific soil quality indices after fire (Cécillon et al., 2009), and recovery of microbial functions after a disturbance (Schimann et al., 2007). The predictions of basal respiration, microbial biomass and catabolic diversity were considered as satisfactory even if they can be improvable. We hypothesised that a strong seasonal variability in the microbial properties between the 4 sampling dates concomitantly with slow evolution of SOM quality and content could have increased the error of prediction. Indeed, Waldrop and Firestone (2006) reported strong seasonal and inter-annual variability in microbial properties of Mediterranean soils. Additionally, FT-NIR spectra are strongly affected by changes in soil organic matter (Foley et al., 1998). However, soil organic matter depletion is a long term degradation process in Mediterranean soils. Thus without seasonal changes in soil organic matter content or composition, the calibration and prediction models cannot explain the part of variance in seasonal variability of microbial activities (Shepherd et al., 2007).

As for microbiological properties, FT-NIR was successful in predicting wildfire history parameters such as time since fire and mean fire interval. The good correlation and prediction of WHI show it is a relevant synthetic index of the effects of the wildfire parameters in the recovery of soil organic matter. These results reflect the strong changes observed in soil organic matter quality along WHI using ${ }^{13} \mathrm{C} N M R$. The number of fire was the least predictable wildfire parameter. This result is in good agreement with the report by Knicker et al. (2006), who concluded that frequent fires do not affect soil organic matter quality more than a single burning. We also supported the hypothesis that fire severity could be a part of the error sources of prediction, as well as fires season unknown in this study.

\section{Conclusions}

The proposed wildfire history index was able to take into account the sensitivity of soil biochemical and microbiological properties to repeated fires in near fire intervals and more especially when fires are recent. Our study also confirms our initial hypothesis that some properties in Mediterranean soils are in equilibrium with wildfire history, up to a limit which depends on number of fires and time since fire. A high fire number (4 fires in 57 years compared to 1-2) resulted in lasting degradation of the soil organic matter inducing a slowdown in the recovery of some microbial properties. Fire histories such as recent or close fires, resulting in substantial losses or alterations of SOM could increase the vulnerability of microbial communities to recurrent Mediterranean drought and heat-waves. As expected, the recovery in microbial catabolic profiles was mainly related to the recovery of the more decomposable fraction of SOM $\left(O\right.$-alkyl $\mathrm{C}$ region of $\left.{ }^{13} \mathrm{C} \mathrm{NMR}\right)$. Finally, 
Guénon R., Vennetier M., Dupuy N., Ziarelli F. and Gros R. (2011) Soil organic matter quality and microbial catabolic functions along a gradient of

Author-produced version of the final draft post-refeering

the original publication is available at www.elsevier.com/locate/issn/09291393 - doi:10.1016/j.apsoil.2011.01.004

Guénon, R. et al., Applied Soil Ecology (2011), doi:10.1016/j.apsoil.2011.01.004

this study demonstrates that FT-NIR analysis can be used as a valuable and inexpensive tool for the assessment of both the wildfire history and the vulnerability of soil quality to shifts in historical fire regime. Our findings could have strong implications regarding programs for soil quality monitoring and restoration.

\section{Acknowledgements}

This study was part of the IRISE project (http://irise.mediasfrance.org/) funded by the European Union, Forest Focus Regulation (No 2152/2003), the French Ministry of Agriculture and Fisheries and ECCOREV Research Federation. Financial support to R. Guénon was provided by the French Agency for Environment and Energy Management (ADEME) and Region Provence-Alpes-Côte d'Azur. Authors are grateful to F. Ruaudel, for her technical assistance. We are very grateful to Mrs. M. Sweetko and M.-L. Guénon for their helpful assistance in English language.

\section{References}

Anderson, J.P.E., Domsch, K.H., 1978. A physiological method for the quantitative measurement of microbial biomass in soils. Soil Biol. Biochem. 10, 215-221.

Baldock, J.A., Masiello, C.A., Gelinas, Y., Hedges, J.I., 2004. Cycling and composition of organic matter in terrestrial and marine ecosystems. Mar. Chem. 92, 39-64.

Baldock, J.A., Oades, J.M., Nelson, P.N., Skene, T.M., Golchin, A., Clarke., P., 1997. Assessing the extent of decomposition of natural 13 organic materials using solid-state ${ }^{13} \mathrm{C}$ NMR spectroscopy. Aust. J. Soil. Res. 35, 1061-1083.

Beare, M.H., Neely, C.L., Coleman, D.C., Hargrove, W.L., 1990. A substrate-induced respiration (SIR) method for measurement of fungal and bacterial biomass on plant residues. Soil Biol. Biochem. 22, 585-594.

Bergner, B., Johnstone, J., Treseder, K.K., 2004. Experimental warming and burn severity alter soil $\mathrm{CO}_{2}$ flux and soil functional groups in a recently burned boreal forest. Glob. Chang. Biol. 10, 1996-2004.

Boerner, R.E.J., Brinkman, J.A., 2003. Fire frequency and soil enzyme activity in southern Ohio oak-hickory forests. Appl. Soil Ecol. 23, 137-146.

Brunet, D., Barthès, B.G., Chotte, J.L., Feller C., 2007. Determination of carbon and nitrogen contents in Alfisols, Oxisols and Ultisols from Africa and Brazil using NIRS analysis: effects of sample grinding and set heterogeneity. Geoderma 139, 106-117.

Campbell, C.D., Cameron, C.M., Bastias, B.A., Chen, C., Cairney, J.W.G., 2008. Long term repeated burning in a wet sclerophyll forest reduces fungal and bacterial biomass and responses to carbon substrates. Soil Biol. Biochem. 40, 2246-2252.

Carreira JA, Niell FX. 1992. Plant nutrient changes in a semi-arid Mediterranean shrubland after fire. J. Veg. Sci., 457-466.

Castells, E., Penuelas, J., Valentine, D.W., 2004. Are phenolic compounds released from the Mediterranean shrub Cistus albidus responsible for changes in N cycling in siliceous and calcareous soils? New Phytol. 162, $187-195$.

Cécillon, L., Cassagne, N., Czarnes, S., Gros, R., Brun, J.J., 2008. Variable selection in near infrared spectra for the biological characterization of soil and earthworm casts. Soil Biol. Biochem. 40, 1975-1979.

Cécillon, L., Cassagne ,N., Czarnes, S., Gros, R., Vennetier, M., Brun, J.J., 2009. Predicting soil quality indices with near infrared analysis in a wildfire chronosequence. Sci. Total Environ. 407, 1200-1205.

Certini, G., 2005. Effects of fire on properties of forest soils: a review. Oecologia 143, 1-10.

Certini, G., Forte, C., D'Acqui, L.P., Santi, C.A., 2007. Spectroscopic properties of bulk and dichromate oxidation resistant soil organic matter from an anthroposequence in a Mediterranean environment. Plant Soil $291,55-65$. 
Guénon R., Vennetier M., Dupuy N., Ziarelli F. and Gros R. (2011) Soil organic matter quality and microbial catabolic functions along a gradient of wildfire history in a Mediterranean ecosystem, Applied Soil Ecology 48 (1) 81-93

Author-produced version of the final draft post-refeering

the original publication is available at www.elsevier.com/locate/issn/09291393 - doi:10.1016/j.apsoil.2011.01.004

Guénon, R. et al., Applied Soil Ecology (2011), doi:10.1016/j.apsoil.2011.01.004

Cheng, C.-H., Lehmann, J., Thies, J.E., Burton, S.D., Engelhard, M.H., 2006. Oxidation of black carbon by biotic and abiotic processes. Org. Geochem. 37, 1477-1488.

Chotte, J.L., Ladd, J.N., Amato M., 1998. Sites of microbial assimilation, and turnover of soluble and particulate ${ }^{14} \mathrm{C}$-labelled substrates decomposing in a clay soil. Soil Biol. Biochem. 30, 205-218.

Cook, R.L., Langford, C.H., Yamdagni, R., Preston, C.M., 1996. A modified cross-polarization magic angle spinning 13C NMR procedure for the study of humic materials. Anal. Chem. 68, 3979- 3986.

Curt, T., Adra, W., Borgniet, L., 2009. Fire-driven oak regeneration in French Mediterranean ecosystems. For. Ecol. Manage. 258, 2127-2135.

D’Ascoli, R., Rutigliano, F.A., De Pascale, R.A., Gentile, A., Virzo De Santo, A., 2005. Functional diversity of the microbial community in Mediterranean maquis soils as affected by fires. Int. J. Wildland Fire 14, 355363.

De Angelis, D.L., Mulholland, P.J., Palumbo, A.V., Steinman, A.D., Huston, M.A., Elwood, J.W., 1989. Nutrient dynamics and food-web stability. Annu. Rev. Ecol. Syst. 20, 71-95.

Degens, B.P., Schipper, L.A., Sparling G.P., Vojvodic-Vukovic., M., 2000. Decreases in organic C reserves in soils can reduce the catabolic diversity of soil microbial communities. Soil Biol. Biochem. 32, 189-196.

Degens, B.P., Schipper, L.A., Sparling, G.P., Duncan, L.C., 2001. Is the microbial community in a soil with reduced catabolic diversity less resistant to stress or disturbance? Soil Biol. Biochem. 33, 1143-1153.

DeLuca, T.H., MacKenzie, M.D., Gundale, M.J., Holben, W.E., 2006. Wildfire-produced charcoal directly influences nitrogen cycling in ponderosa pine forests. Soil Sci. Soc. Am. J. 70, 448-453.

Derenne, S., Largeau, C., 2001. A review of some important families of refractory macromolecules: composition, origin, and fate in soils and sediments. Soil Science 166, 833-847.

Eckmeier, E., Wiesenberg, G.L.B., 2009. Short-chain n-alkanes (C16-20) in ancient soil are useful molecular markers for prehistoric biomass burning. J. Archaeol. Sci. 36, 1590-1596.

Flannigan, M.D., Stocks, B.J., Wotton, B.M., 2000. Climate change and forest fires. Sci. Total Environ. 262, 221-229.

Foley, W.J., Mcllwee, A., Lawler, I., Aragones, L., Woolnough, A.W., Berding, N., 1998. Ecological applications of near infrared reflectance spectroscopy - a tool for rapid, cost-effective prediction of the composition of plant and animal tissues and aspects of animal performance. Oecologia 116, 293-305.

Forte, C., Piazzi, A., Pizzanelli, S., Certini, G., 2006. CP MAS 13C spectral editing and relative quantitation of a soil sample. Solid State Nucl. Magn. Reson. 30, 81-88.

Garland, J.L., Mills, A.L., 1991. Classification and characterisation of heterotrophic microbial communities on the basis of patterns of community-level sole-carbon-source utilisation. Appl. Environ. Microbiol. 57, 2351-2359.

Gill, A.M., 1975. Fire and the Australian Flora. A review. Aust. For. 38, 4-25.

Giovannini G, Lucchesi S, Giachetti M (1988) Effects of heating on some physical and chemical parameters related to soil aggregation and erodibility. Soil Sci 146:255-261

Gelinas, Y., Baldock, J.A., Hedges, J.I., 2001. Demineralization of marine and freshwater sediments ${ }^{13} \mathrm{C}$ NMR analysis for CP/MAS. Org. Geochem. 32, 677-693.

Gerbaud, G., Ziarelli, F., Caldarelli, S., 2003. Increasing the robustness of heteronuclear decoupling in magicangle sample spinning solid-state NMR. Chem. Phys. Lett. 377, 1-5.

Gershenzon, J., 1984. Changes in the levels of plant secondary metabolite production under water and nutrient stress. Recent Adv. Phytochem. 18, 273-320.

González-Pérez, J.A., González-Vila, F.J., Almendros, G., Knicker, H., 2004. The effect of fire on soil organic matter-a review. Environ. Int. 30, 855-870. 
Guénon R., Vennetier M., Dupuy N., Ziarelli F. and Gros R. (2011) Soil organic matter quality and microbial catabolic functions along a gradient of wildfire history in a Mediterranean ecosystem, Applied Soil Ecology 48 (1) 81-93

Author-produced version of the final draft post-refeering

the original publication is available at www.elsevier.com/locate/issn/09291393 - doi:10.1016/j.apsoil.2011.01.004

Guénon, R. et al., Applied Soil Ecology (2011), doi:10.1016/j.apsoil.2011.01.004

González-Vila, F.J., González, J.A., Polvillo, O., Almendros, G., Knicker, H., Nature of refractory forms of organic carbon in soils affected by fires. 2002. Pyrolytic and spectroscopic approaches. In: Viegas DX, editor. Forest fire research and wildland fire safety. Rotterdam: Millpress.

Grime, J.P., 1979, Plant strategies and vegetation processes. John Wiley amd Sons, Chichester.

Guénon, R., Pailler, A., Dupuy, N., Vennetier, M., Roussos, S., Gros, R., Trends in recovery of Mediterranean soil chemical properties and microbial activities after infrequent and frequent wildfires. Submitted to Land Degradation and Development.

Guinto, D.F, Saffigna, P.G., Xu, Z.H., House, A.P.N., Perera, M.C.S., 1999. Soil nitrogen mineralisation and organic matter composition ${ }^{13} \mathrm{C}$ NMR spectroscopy under repeated prescribed revealed by burning in eucalypt forests of south-east Queensland. Aust. J. Soil. Res. 37, 123-135.

Hart, S.C., Newman, G.S., DeLuca, T.H., MacKenzie, M.D., Boyle, S.I., 2005. Post-fire vegetative dynamics as drivers of microbial community structure and function in forest soils. For. Ecol. Manage. 220, 166-184.

Hatten, J.A., Zabowski, D., Ogden, A., Thies, W., 2008. Soil organic matter in a ponderosa pine forest with varying seasons and intervals of prescribed burn. For. Ecol. Manage. 255, 2555-2565.

Hernández, T., Garcia, C., Reinhardt, I., 1997. Short-term effects of wildfire on the chemical, biochemical, and microbiological properties of Mediterranean pine forest soils. Biol. Fertil. Soils 25, 109-116.

Hilscher, A., Heister, K., Siewert, C., Knicker, H., 2009. Mineralisation and structural changes during the initial phase of microbial degradation of pyrogenic plant residues in soil. Org. Geochem. 40, 332-342.

Hopkins, D.W., Chudek., J.A., 1997. Solid-state NMR investigations of organic transformations during the decomposition of plant material in soil. p. 85-94. In G. Cadisch and K.E. Giller (ed.) Driven by nature: Plant litter quality and decomposition. CAB Int., Wallingford, UK.

IUSS Working Group WRB. 2006. World reference base for soil resources 2006. 2nd edition. World Soil Resources Reports No. 103. FAO, Rome.

Knell, R.J., 2009. On the analysis of non-linear allometries. Ecol. Entomol. 34, 1-11.

Knicker, H., 2004. Stabilization of N-compounds in soil and organic matter-rich sediments - what is the difference? Mar. Chem. 92, 167-195.

Knicker, H., González-Vila, F.J., Polvillo, O., Gonzàlez, J.A., Almendros, G., 2005. Fire-induced transformation of $\mathrm{C}$ - and $\mathrm{N}$ - forms in different organic soil fractions from a Dystric Cambisol under a Mediterranean pine forest (Pinus pinaster). Soil Biol. Biochem. 37, 701-718.

Knicker, H., Almendros, G., González-Vila, F.J., Gonzàlez-Pérez, J.A., Polvillo, O., 2006. Characteristic alterations of quantity and quality of soil organic matter caused by forest fires in continental Mediterranean ecosystems: a solid state ${ }^{13}$ C NMR study. Eur. J. Soil Sci. 57, 558-569.

Knicker, H., 2007. How does fire affect the nature and stability of soil organic nitrogen and carbon? A review. Biogeochemistry 85, 91-118.

Kögel-Knabner, I., 2002. The macromolecular organic composition of plant and microbial residues as inputs to soil organic matter. Soil Biol. Biochem. 34, 139-162.

Lützow, M.v., Kögel-Knabner, I., Ekschmitt, K., Matzner, E., Guggenberger, G., Marschner, B., Flessa, H., 2006. Stabilization of organic matter in temperate soils: mechanisms and their relevance under different soil conditions - a review. Eur. J. Soil Sci. 57, 426-445.

Martins, C.M.C., Mesquita, S.M.M., Vaz, W.L.C., 1999. Cuticular waxes of the holm (Quercus ilex 1. subsp. ballota (desf.) samp.) and cork (Q. suber 1.) oaks. Phytochem. Anal. 10, 1-5.

Massiot, D., Fayon, F., Capron, M., King, I., Le Calvé, S., Alonso, B., Durand, J-O., Bujoli, B., Gan, Z., Hoatson, G., 2002. "Modelling one- and two-dimensional Solid State NMR spectra.", Magn. Reson. Chem. 40, 70-76. 
Guénon R., Vennetier M., Dupuy N., Ziarelli F. and Gros R. (2011) Soil organic matter quality and microbial catabolic functions along a gradient of wildfire history in a Mediterranean ecosystem, Applied Soil Ecology 48 (1) 81-93

Author-produced version of the final draft post-refeering

the original publication is available at www.elsevier.com/locate/issn/09291393 - doi:10.1016/j.apsoil.2011.01.004

Guénon, R. et al., Applied Soil Ecology (2011), doi:10.1016/j.apsoil.2011.01.004

Mathers, N.J., Mendham, D.S., O'Connell, A.M., Grove, T.S., Xu, Z., Saffigna, P.G., 2003. How does residue management impact soil organic matter composition and quality under Eucalyptus globules plantations in southwestern Australia? For. Ecol. Manage. 179, 253-267.

Merrill, D.F., Alexander, M.E., editors. 1987. Glossary of forest fire management terms. 4th ed. National Research Council of Canada, Canadian Committee on Forest Fire Management, Ottawa. Publication NRCC No. 26516.91p.

Mills, A.J., Fey, M.V., 2004. Frequent fires intensify soil crusting: physiochemical feedback in the pedoderm of long-term burn experiments in South Africa. Geoderma 121, 45-64.

Moore, J.C., de Ruiter, P.C., Hunt, H.W., 1993. Influence of productivity on the stability of real and model ecosystems. Science 261, 906-908.

Oosterbaan, R.J., 1994. Frequency and regression analysis. Drainage Principles and Applications (ed. by H.P. Ritzema), pp. 175-224. ILRI, Wageningen, The Netherlands.

Orwin, K.H., Wardle, D.A., Greenfield, L.G., 2006. Ecological consequences of carbon substrate identity and diversity in a laboratory study. Ecology 87, 580-593.

Paul, E.A., Clark F.E., 1989. Soil microbiology and biochemistry. Academic press, Inc., New York.

Pausas, J.G., Ribeiro, E., Vallejo, R., 2004. Post-fire regeneration variability of Pinus halepensis in the eastern Iberian Peninsula. Forest Ecology and Management 203, 251-259.

Pietikäinen, J., Hiukka, R., Fritze, H., 2000. Does short-term heating of forest humus change its properties as a substrate for microbes? Soil Biol. Biochem. 32, 277-288.

Prieto-Fernández, A., Acea, M.J., Carballas, T., 1998. Soil microbial and extractable C and N after wildfire. Biol. Fertil. Soils 27, 132-142.

Preston, C.M., Trofymow, J.A., Sayer, B.G., Niu, J., 1997. ${ }^{13}$ C nuclear magnetic resonance spectroscopy with cross polarization and magic angle spinning investigation of the proximate-analysis fractions used to assess litter quality in decomposition studies. Can. J. Bot. 75, 1601-1613.

Radford, J.Q., Bennett, A.F., Cheers, G.J., 2005. Landscape-level thresholds of habitat cover for woodlanddependent birds. Biol. Conserv. 124, 317-337.

Reich, P.B., Peterson, D.W., Wedin, D.A., Wrage, K., 2001. Fire and vegetation effects on productivity and nitrogen cycling across a forest-grassland continuum. Ecology 82, 1703-1719.

Rumpel, C., Chaplot, V., Planchon, O., Bernadou, J., Valentin, C., Mariotti, A., 2006.

Preferential erosion of black carbon on steep slopes with slash and burn agriculture. Catena 65, 30-40.

Rutigliano, F.A., D'Ascoli, R., Virzo De Santo A. 2004. Soil microbial metabolism and nutrient status in a Mediterranean area as affected by plant cover. Soil Biol. Biochem. 36, 1719-1729.

Santín, C., Knicker, H., Fernández, S., Menéndez-Duarte, R., Álvarez, M.Á., 2008. Wildfires influence on soil organic matter in an Atlantic mountainous region (NW of Spain). Catena 74, 286-295.

Schaefer, J., Stejskal, E.O.R., 1976. Carbon-13 nuclear magnetic resonance of polymers spinning at magic angle. J. Am. Chem. Soc. 98, 1031-1032.

Scheffer, M., Carpenter, S., 2003. Catastrophic regime shifts in ecosystems: linking theory to observation. Trends Ecol. Evol. 18, 648-656.

Schimann, H, Joffre, R., Roggy, J-C., Lensi, R., Domenach, A-M., 2007. Evaluation of the recovery of microbial functions during soil restoration using near-infrared spectroscopy. Appl. Soil Ecol. 37, 223-232.

Schipper, L.A., Degens, B.P., Sparling, G.P., Duncan, L., C. 2001. Changes in microbial heterotrophic diversity along five plant successional sequences. Soil Biol. Biochem. 33, 2093-2103. 
etier M. Dupuy N., Ziarelli F. and Gros R. (2011) Soil organic matter quality and microbial catabolic functions along a gradient of wildfire history in a Mediterranean ecosystem, Applied Soil Ecology 48 (1) 81-93

Author-produced version of the final draft post-refeering

the original publication is available at www.elsevier.com/locate/issn/09291393 - doi:10.1016/j.apsoil.2011.01.004

Guénon, R. et al., Applied Soil Ecology (2011), doi:10.1016/j.apsoil.2011.01.004

Shephers, K.D., Walsh, M.G., 2007. Infrared spectroscopy-enabling an evidence-based diagnostic surveillance approach to agricultural and environmental management in developing countries. J. NIRS 15, 119.

Simpson, E.H., 1949. Measurement of diversity. Nature 163, 688.

Skjemstad, J.O., Taylor, J.A., Smernik, R.J., 1999. Estimation of charcoal (char) in soils. Comm. Soil Sci. Plant Anal. 30, 2283-2298.

ter Braak, C.J.F., Smilauer, P., 2002. CANOCO Reference Manual and CanoDraw for Windows User's Guide: Software for Canonical Community Ordination (version 4.5). Ithaca, NY, USA: Microcomputer Power. 500.

Tenenhaus, M., 1998. La régression PLS. Théorie et pratique, Editions Technip, Paris.

Vergnoux, A., Dupuy, N., Guiliano, M., Vennetier, M., Théraulaz, F., Doumenq, P., 2009. Fire impact on forest soils evaluated using near-infrared spectroscopy and multivariate calibration. Talanta 80, 39-47.

Vilà, M., Sardans, J., 1999. Plant competition in mediterranean-type vegetation. J. Veg. Sci. 10, 281-294.

Waldrop, M.P., Firestone, M.K., 2006. Seasonal dynamics of microbial community composition and function in oak canopy and open grassland soils. Microb. Ecol. 52, 470-479.

Webster, E.A., Hopkins, D.W., Chudek, J.A., Haslam, S.F.I., Simek, M., Picek, T., 2001. The relationship between microbial carbon and the resource quality of soil carbon. J. Environ. Qual. 30, 147-150.

Wilson, M.A., Heng, S., Goh, K.H., Pugmire, R.J., Grant, D.M., 1983. Studies of litter and acid insoluble soil organic matter fractions using 13C-cross polarization nuclear magnetic resonance spectroscopy with magic angle spinning. J. Soil Sci. 34, 83-97.

Zhou, L., Huang, J., Lu, F., Han, X., 2009. Effects of prescribed burning and seasonal and interannual climate variation on nitrogen mineralization in a typical steppe in Inner Mongolia. Soil Biol. Biochem. 41, 796-803. 